\title{
Analytical and numerical study of the salinity intrusion in the Sebou river estuary (Morocco) - effect of the "Super Blood Moon" (total lunar eclipse) of 2015
}

\author{
Soufiane Haddout, Mohammed Igouzal, and Abdellatif Maslouhi \\ Interdisciplinary Laboratory for Natural Resources and Environment, Department of Physics, Faculty of Sciences, \\ Ibn Tofail University, B.P 242, 14000 Kenitra, Morocco \\ Correspondence to: Soufiane Haddout (haddout.ens@gmail.com)
}

Received: 31 May 2016 - Published in Hydrol. Earth Syst. Sci. Discuss.: 13 June 2016

Revised: 29 August 2016 - Accepted: 12 September 2016 - Published: 26 September 2016

\begin{abstract}
The longitudinal variation of salinity and the maximum salinity intrusion length in an alluvial estuary are important environmental concerns for policy makers and managers since they influence water quality, water utilization and agricultural development in estuarine environments and the potential use of water resources in general. The supermoon total lunar eclipse is a rare event. According to NASA, they have only occurred 5 times in the 1900s - in 1910, 1928, 1946, 1964 and 1982. After the 28 September 2015 total lunar eclipse, a Super Blood Moon eclipse will not recur before 8 October 2033. In this paper, for the first time, the impact of the combination of a supermoon and a total lunar eclipse on the salinity intrusion along an estuary is studied. The 28 September 2015 supermoon total lunar eclipse is the focus of this study and the Sebou river estuary (Morocco) is used as an application area. The Sebou estuary is an area with high agricultural potential, is becoming one of the most important industrial zones in Morocco and it is experiencing a salt intrusion problem. Hydrodynamic equations for tidal wave propagation coupled with the Savenije theory and a numerical salinity transport model (HEC-RAS software "Hydrologic Engineering Center River Analysis System") are applied to study the impact of the supermoon total lunar eclipse on the salinity intrusion. Intensive salinity measurements during this extreme event were recorded along the Sebou estuary. Measurements showed a modification of the shape of axial salinity profiles and a notable water elevation rise, compared with normal situations. The two optimization parameters (Van der Burgh's and dispersion coefficients) of the analytical model are estimated based on the LevenbergMarquardt's algorithm (i.e., solving nonlinear least-squares
\end{abstract}

problems). The salinity transport model was calibrated and validated using field data. The results show that the two models described very well the salt intrusion during the supermoon total lunar eclipse day. A good fit between computed salinity and measurements is obtained, as verified by statistical performance tests. These two models can give a rapid assessment of salinity distribution and consequently help to ensure the safety of the water supply, even during such infrequent astronomical phenomenon.

\section{Introduction}

A supermoon total lunar eclipse is one of nature's loveliest celestial events (Espenak, 2000). During this event, three things will occur at once. First, the moon will be both full and at its closest point to Earth $(356877 \mathrm{~km})$; this is known as a supermoon or perigee Moon (NASA, 2015). Second, this will occur at the same time as a total lunar eclipse; that means the Moon, Sun and Earth will be aligned. Because of its proximity to Earth, the Moon will appear brighter and larger (14\% larger and 30\% brighter than other full moons) in the sky (NASA, 2015). Third, the moon will appear a dark, coppery red, caused by the Earth blocking the sun light that is refracted by the atmosphere into the umbra (Hughes et al., 2015) (Fig. 1). Furthermore, tidal motions are controlled by changes in the position and alignment of the Moon and Sun relative to Earth (Stronach, 1989) (Fig. 2). Therefore, tidal forces are strengthened if the moon is closest to Earth in its 


\section{Total Lunar Eclipse of 2015 Sep 28}

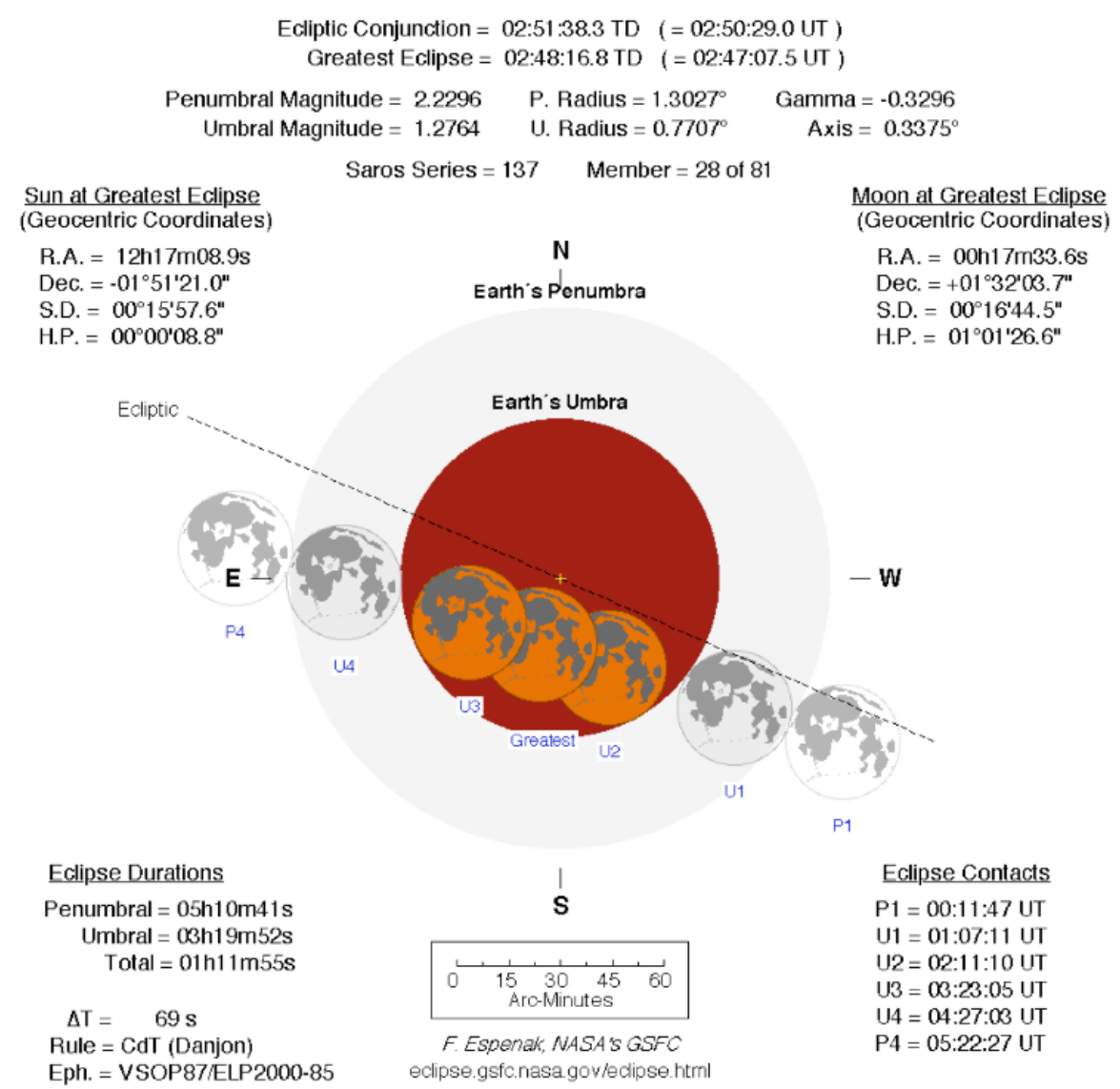

Figure 1. Total lunar eclipse calculation by Fred Espenak, NASA/GSFC.

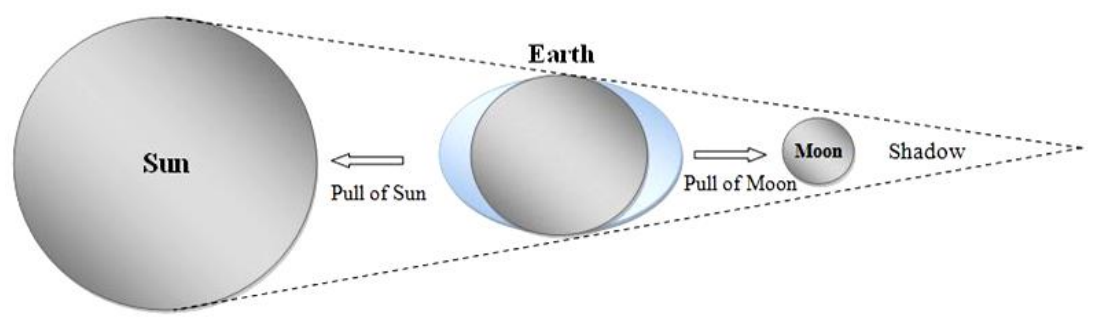

Figure 2. Illustrating the position of the moon (total lunar eclipse).

elliptical orbit and when the Sun and Moon are directly over the Equator (NOC, 2015).

Estuaries form essential parts of the human-Earth system (Savenije, 2015). As the connecting element between marine water and river, estuaries have properties of both: they contain both fresh and saline water, they experience not only tides but also river floods, and they host both saline and fresh ecosystems (Savenije, 2015). The diverse estuarine environment plays not only an important role in the life cycle of many species but also serves as a site for many human ac- tivities. In short, estuaries are important water bodies where many dynamic factors interact and unfold (Xu et al., 2015). For decades, explosive increases in industrial and agricultural productivity, as well as the growing population in estuary regions, have led to numerous environmental concerns (Mai et al., 2002). Salinity intrusion is an important phenomenon in an estuary, and can constitute a serious problem. It influences the water quality and threatens potential water resource use. Intake of fresh water for consumption, agricultural purposes or use by industries may take place within a region 
not far landward of the limit of salt intrusion. To support policy and managerial decisions, a profound knowledge of processes associated with the salinity structure in estuaries is required (Kuijper and Van Rijn, 2011). Models have been widely used to research salinity intrusion. Two kinds of models are typically used: numerical models and analytical models. Presently, numerical models are more popular especially two-dimensional (2-D) and 3-D models (Kärnä et al., 2015; Elias et al., 2012; Zhao et al., 2012; Li et al., 2012; Jeong et al., 2010; Wu and Zhu, 2010; Xue et al., 2009; An et al., 2009 , etc.) because they can provide more spatial and temporal detail.

Analytical models are also widely used, such as Prandle (1981), Savenije (1986, 1989, 1993a, 2005, 2012, 2015), Lewis and Uncles (2003), Gay and O'Donnell (2007, 2009), Kuijper and Van Rijn (2011), Aertsl et al. (2000), Brockway et al. (2006), Nguyen and Savenije (2006), Nguyen (2008), Nguyen et al. (2008), Cai et al. (2016), Gisen et al. (2015a, b), and Xu et al. (2015). These tools are based on the steadystate conservation of mass equation, which indicates that the dispersive and advective transports of salt are in equilibrium and the effective longitudinal dispersion coefficient incorporates all mixing mechanisms, where the dispersion coefficient along the estuary axis is either constant (e.g., Brockway et al., 2006; Gay and O'Donnell, 2007) or variable (e.g., Van der Burgh, 1972; Savenije, 1986).

In fact, 1-D mathematical models, i.e. analytical or numerical, can constitute the appropriate tools for quick-scan actions in a pre-phase of a project or for instructive purposes. In addition, it is methodologically correct to start with the simplest description of the phenomena under study and to evaluate the limits of this approximation before investigating more complications.

Our previous studies on the Sebou river estuary have shown that the 1-D (analytical or numerical) methods properly compute salt intrusion (Haddout et al., 2015, 2016). Also, Haddout et al. (2015) showed that salinity profiles of Sebou estuary show steep decrease. This characteristic is specific to narrow estuaries, i.e., having a near-prismatic shape and significant freshwater discharge. Such estuaries are called positive estuaries.

The aims of this paper it to investigate the applicability of these two methods, analytical or numerical, during the supermoon total lunar eclipse day of 28 September 2015. Measurements have shown a modification of the shape of the salinity profiles along the estuary and a notable water level increase, compared with normal situations studied in our earlier works. In addition, calculations during the supermoon total lunar eclipse using the coupled analytical hydrodynamic-salt intrusion model required the recalculation of the geometric parameters of the estuary i.e., cross-sectional area $A_{0}$ and convergence length $a$.

Even in these extreme conditions, a good-fit was obtained between the computed and observed salinity distribution for the two models. These models constitute powerful tools for evaluating salinity intrusion patterns in the Sebou river estuary, even during extreme events inducing sea level rise like the supermoon eclipse or climate change.

\section{Models formulations}

\section{$2.1 \quad$ 1-D salt intrusion model}

The analytical salinity intrusion model of Savenije (2005) has been adopted to predict the salinity distribution and salinity intrusion length in alluvial estuaries. This method is fully analytical, although it makes use of certain assumptions, the most important being: the exponential shape of the estuary, the longitudinal variation of the dispersion according to Van der Burgh (1972), and the predictive equations for the boundary condition and the Van der Burgh coefficient. The equations are based on the 1-D cross-sectionally averaged, and tidally averaged, steady-state salt balance equation, in which the advective salt transport is caused by the seaward freshwater discharge, counteracted by the landward dispersive salt transport induced by the different mixing processes (Cai et al., 2015). In a convergent estuary, the main geometric parameters: cross-sectional area $A$, width $B$ and depth $h$ can be described by exponential functions (see Eqs. (2.38)-(2.40) in Savenije, 2012).

In a steady-state situation, the partial temporal derivative in the salt balance equation is zero (Gisen et al., 2015b). Considering constant freshwater discharge $Q$ and tidally averaged cross-sectional area $A$, the salt balance equations for the high water slack (HWS), low water slack (LWS) and tidal average (TA) situation can be rearranged as

$\frac{\partial S}{S}=-\frac{|Q|}{A D} \partial x$.

If one assumes that $D$ is constant along the length of an estuary, i.e., $D=D_{0}$, where $D_{0}$ is the dispersion coefficient at the estuary mouth, simple analytical solutions for axial distribution of salinity can be derived.

Since dispersion depends both on the river discharge and the salinity distribution itself, the constant dispersion is not a correct solution. An efficient and accurate approach to simulate the longitudinal variation of dispersion is presented by Van der Burgh (1972), and also adopted by Savenije (1986, 1989, 1993a, 2005, 2012):

$$
\frac{\partial D}{\partial x}=-K \frac{|Q|}{A},
$$

which, using Eq. (1), can be demonstrated to be the same as the following equation (Savenije, 2005, 2012):

$$
\frac{D}{D_{0}}=\left[\frac{S}{S_{0}}\right]^{K} \text {, }
$$

where $S_{0}\left(\mathrm{~g} \mathrm{~L}^{-1}\right)$ is the boundary salinity at the estuary mouth, $D_{0}\left(\mathrm{~m}^{2} \mathrm{~s}^{-1}\right)$ is the longitudinal dispersion at the estuary mouth for the HWS, LWS or TA condition and $K$ is the 
Van der Burgh's dimensionless coefficient, which has a value between 0 and 1 . If $K=0$, Eq. (3) reduces to the case with constant dispersion $D=D_{0}$. For the case where $K=1$, we see that the curves $D / D_{0}$ and $S / S_{0}$ coincide. If $K$ is small, then tide-driven mixing is dominant near the toe of the intrusion curve; if $K$ approaches unity, then gravitational mixing is dominant (Savenije, 2006; Shaha and Cho, 2011).

Integrating Eq. (3) in combination with Eq. (2.38) in Savenije (2012) yields

$$
\frac{D}{D_{0}}=\left[1-\frac{K|Q| a}{A D_{0}}\{\exp (x / a)-1\}\right]
$$

which determines the longitudinal variation of dispersion coefficient. Combining Eqs. (3) and (4), the cross-sectionally averaged salinity along an estuary with convergent crosssectional area is given by Savenije $(2005,2012)$ :

$$
\frac{S}{S_{0}}=\left[1-\frac{K|Q| a}{D_{0} A_{0}}(\exp (x / a)-1)\right]^{1 / K} \text {. }
$$

Making use of the dimensionless parameters (Cai et al., 2016), Eq. (5) can be scaled as

$$
S^{*}=\left[1-\frac{K D^{*}}{\gamma}\left(\exp \left(x^{*} \gamma\right)-1\right)\right]^{1 / K},
$$

where $S^{*}$ is dimensionless salinity that is normalized by the salinity at the estuary mouth, $\gamma$ is the estuary shape number representing the convergence of an estuary, $D^{*}$ is the dimensionless dispersion at seaward boundary condition and $x^{*}$ is the dimensionless longitudinal coordinate that is scaled by the frictionless wavelength in prismatic channels (Cai et al., 2016).

This 1-D steady advection-diffusion model has been applied to describe the salinity distribution along numerous well-mixed and partially-mixed estuaries (i.e. the adopted salt intrusion model assumes a partially to well mixed situation, which under low flow is the dominant process) (Nguyen and Savenije, 2006) for the HWS, LWS or TA condition.

The salt intrusion length $L^{*}$, defined as the distance from the estuary mouth to the location with freshwater salinity (assumed to be $<1 \mathrm{~g} \mathrm{~L}^{-1}$ isohaline) for the HWS, LWS or TA condition, can be determined by setting $S^{*}=0$ in Eq. (6):

$L^{*}=\frac{1}{\gamma} \ln \left(\frac{\gamma}{D^{*} K}+1\right)$.

Furthermore, in most estuaries, there usually exists an inflection point near the mouth, where the geometry changes (e.g., Gisen et al., 2015b). This inflection point is associated with the transition of a wave-dominated regime to a tidedominated regime (Gisen et al., 2015b). Making use of this phenomenon, Gisen et al. (2015b) recently expanded the underlying database and reanalyzed these equations, resulting in

$$
\frac{D_{1}}{v_{1} E_{1}}=\left[0.396 \times\left(g / C^{2}\right)^{0.21}\left(N_{\mathrm{R}}\right)^{0.57}\right] \text {, }
$$

$$
K=8.03 \times 10^{-6}\left[\frac{B_{f}^{0.30} g^{0.93} H_{1}^{0.13} T^{0.97} \pi^{0.71}}{B_{1}^{0.30} C_{z}^{0.18} v_{1}^{0.71} b_{1}^{0.11} h_{1}^{0.15} r_{s}^{0.84}}\right],
$$

where $B_{f}$ is the river regime width (typical width in the river-dominated region), and $C_{z}$ is the Chezy roughness coefficient. The symbols $H_{1}(\mathrm{~m}), B_{1}(\mathrm{~m}), v_{1}\left(\mathrm{~m} \mathrm{~s}^{-1}\right), b_{1}(\mathrm{~m})$, $h_{1}(\mathrm{~m}), D_{1}\left(\mathrm{~m}^{2} \mathrm{~s}^{-1}\right)$ and $E_{1}(\mathrm{~m})$ represent the tidal range, stream width, velocity amplitude, width convergence length, depth, dispersion coefficient and tidal excursion at the inflection point, respectively. If there is no inflection point near the estuary mouth, then these parameters refer to the situation at the mouth itself.

The roughness coefficient can be estimated by $C_{z}=$ $K_{\mathrm{s}} h_{1}^{1 / 6}$ with $K_{s}$ being the Manning-Strickler friction $\left(K_{s}=\right.$ $1 / n$, where $n$ is the Manning's coefficient), while the tidal excursion can be calculated by $E_{1}=v_{1} T / \pi$. The estuarine Richardson number $N_{\mathrm{R}}$, which is defined as the ratio of potential energy of the buoyant fresh water to the kinetic energy of the tide (Fischer et al., 1979), is given by

$N_{\mathrm{R}}=\frac{\Delta \rho}{\rho} \frac{g h|Q| T}{A_{0} E_{0} v_{0}^{2}}$,

where $\rho\left(\mathrm{kg} \mathrm{m}^{-3}\right)$ is the water density, $\Delta \rho$ is the density difference of ocean and river water over the salt intrusion length (in estuaries, the ratio $\Delta \rho / \rho$ is about 0.025 ).

\subsection{Analytical hybrid model}

Since 1960s there has existed a long tradition of 1-D analytical solutions for tidal dynamics in estuaries (e.g., Dronkers, 1964; Ippen, 1966; Prandle and Rahman, 1980; Leblond, 1978; Godin, 1985, 1999; Jay, 1991; Savenije, 1993b; Friedrichs and Aubrey, 1994; Lanzoni and Seminara, 1998; Kukulka and Jay, 2003; Horrevoets et al., 2004; Jay et al., 2011; Cai et al., 2012a). These analytical solutions usually made assumptions to simplify or linearize the nonlinear set of equations (Zhang et al., 2012). Of these, most authors used perturbation analysis, where scaled equations are simplified by discarding higher-order terms, generally neglecting the advective acceleration term and linearizing the friction term higher-order terms, whereas Savenije (2005) uses a simple harmonic solution without simplifying the equations (Cai et al., 2013). Others used a regression model to determine the relationship between river discharge and tide. Exceptions are the approaches by Horrevoets et al. (2004) and Cai et al. (2012b), who provided analytical solutions accounting for river discharge, based on the envelope method originally developed by Savenije (1998) (Cai et al., 2013). Recently, Cai et al. (2012a) proposed a new analytical framework for understanding the tidal damping in estuaries. They concluded that the main differences between the examined models (e.g., Savenije et al., 2008; Toffolon and Savenije, 2011; Kuijper and Van Rijn, 2011) lies in the treatment of the friction term in the momentum equation. Furthermore, Cai et al. (2012a) presented a new "hybrid" expression for tidal damping as a 
Table 1. Definition of dimensionless parameters (Cai et al., 2015).

\begin{tabular}{ll}
\hline \multicolumn{2}{c}{ Dimensionless parameters } \\
\hline Local variable & Dependent variable \\
Tidal amplitude & Damping number \\
$\zeta=\eta / h$ & $\delta=c_{0} d \eta /(\eta \omega d x)$ \\
Estuary shape & Velocity number \\
$\gamma=c_{0} /(\omega a)$ & $\mu=v /\left(r_{\mathrm{s}} \zeta c_{0}\right)=$ \\
Friction number & $v h /\left(r_{\mathrm{s}} \eta c_{0}\right)$ \\
$\chi=r_{\mathrm{s}} f c_{0} \zeta /(\omega h)$ & Celerity number \\
River discharge & $\lambda=c_{0} / c$ \\
$\varphi=U_{r} / v$ & Phase lag \\
& $\varepsilon=\pi / 2-\left(\phi_{Z}-\phi_{U}\right)$ \\
\hline
\end{tabular}

weighted average of the linearized and fully nonlinear friction term (Cai et al., 2013). Additionally, Cai et al. (2014b) included for the first time the effect of river discharge in a hybrid model that performs better.

It can be demonstrated that tidal hydrodynamics is controlled by three-dimensionless parameters that depend on localized geometry and external forcing (e.g., Toffolon et al., 2006; Savenije et al., 2008), i.e., $\zeta$ the dimensionless tidal amplitude (indicating the seaward boundary condition), $\gamma$ the estuary shape number (representing the effect of crosssectional area convergence) and $\chi$ the friction number (describing the role of the frictional dissipation). These parameters are defined in Table 1, where $\eta$ is the tidal amplitude and $K_{S}$ is the Manning-Strickler friction coefficient.

Note that the friction number reflects the nonlinear effect of the varying depth (Savenije, 2012). The tidal hydrodynamics analytical solution can be obtained by solving a set of four analytical equations, i.e., the phase lag equation, the scaling equation, the damping equation and the celerity equation (Cai et al., 2013). In Table 2, we present these equations for the general case as well as the special case of the ideal estuary $(\delta=0)$.

\subsection{Coupled model for salt intrusion}

Since tidal dynamics in convergent alluvial estuaries can be reproduced reasonably well by 1-D analytical solutions, in principle the output of such a model can be used to predict the longitudinal tidal excursion $E^{*}$; i.e. $E^{*}$ is the dimensionless tidal excursion scaled by the frictionless tidal wavelength (Cai et al., 2016) defined as

$E^{*}=E \omega / c_{0}=2 v / c_{0}, \quad v=r_{\mathrm{s}} c_{0} \mu \omega, \eta / h$,

where $v$ is the velocity amplitude and $\omega$ is the tidal frequency, $c_{0}$ is the classical wave celerity of a frictionless progressive wave defined as

$c_{0}=\sqrt{g h / r_{\mathrm{s}}}$,

where $g$ is the acceleration due to gravity and $r_{\mathrm{s}}$ the storage width ratio (e.g., Savenije et al., 2008).
Moreover, Van der Burgh (1972) assumed that the salinity curves for the HWS and LWS situations can be obtained by applying a horizontal translation over half the tidal excursion in the landward and seaward direction from TA situation and subsequently was demonstrated by Savenije (1986, 1989, 2005, 2012). Thus, Eq. (6) can be used to describe the two situations of

$S^{* \operatorname{HWS}}\left(x^{*}\right)=S^{*} \mathrm{TA}\left(x^{*}+E^{*} / 2\right)$,

$S^{* \mathrm{LWS}}\left(x^{*}\right)=S^{* \mathrm{TA}}\left(x^{*}-E^{*} / 2\right)$.

Here the asterisk denotes a dimensionless variable.

The proposed analytical model by Cai et al. (2012a) for tidal hydrodynamics can be used to predict a variable velocity amplitude $v$ (and hence tidal excursion $E^{*}$ ) for given tidal amplitude at the seaward boundary, estuary shape and friction.

\subsection{Numerical modeling}

\subsubsection{Hydrodynamic model}

Salinity distribution is influenced by the hydrodynamic regime, which in turn depends highly on the river estuary morphology. In the hydrodynamics module, HEC-RAS solves the following 1-D equations of continuity and momentum, known as the Saint-Venant equations (Brunner, 2010):

$$
\begin{aligned}
& \frac{\partial Q}{\partial x}+\frac{\partial A}{\partial t}-q_{l}=0, \\
& \frac{\partial Q}{\partial t}+\frac{\partial\left(Q^{2} / A\right)}{\partial x}+g A \frac{\partial h}{\partial x}=g A\left\{\left[\frac{n Q}{A R^{2 / 3}}\right]^{2}-\beta_{0}\right\},
\end{aligned}
$$

where $Q$ is the freshwater discharge $\left(\mathrm{m}^{3} \mathrm{~s}^{-1}\right), A$ is the crosssectional area $\left(\mathrm{m}^{2}\right), x$ is the distance along the channel $(\mathrm{m}), t$ is the time (s), $q_{l}$ is the lateral inflow per unit length $\left(\mathrm{m}^{2} \mathrm{~s}^{-1}\right)$, $g$ is the acceleration due to gravity $\left(\mathrm{m} \mathrm{s}^{-2}\right), h$ is the flow depth $(\mathrm{m}), \beta_{0}(-)$ is the bottom slope, $n$ is the Manning's roughness coefficient $\left(n=1 / K_{\mathrm{s}}\right)\left(\mathrm{m}^{-1 / 3} \mathrm{~s}^{-1}\right)$ and $R$ is the hydraulic radius $(\mathrm{m})$.

Manning's roughness coefficient used in the momentum equation is evaluated initially by the empirical formula Eq. (16) proposed by Cowan (1956) and Chow (1959):

$n=\left(n_{0}+n_{1}+n_{2}+n_{3}+n_{4}\right) m_{5}$,

where $n_{0}$ is a basic value for a straight, uniform, smooth channel, $n_{1}$ is the adjustment for the effect of surface irregularity, $n_{2}$ is the adjustment for the effect of variation in shape and size of the channel cross section, $n_{3}$ is the adjustment for obstruction, $n_{4}$ is the adjustment for vegetation and $m_{5}$ is a correction factor for meandering channels.

Equations (14) and (15) are solved using the well-known four-point implicit box finite difference scheme (Brunner, 2010). 
Table 2. Hybrid solution of tidal wave propagation in convergent estuaries (Cai et al., 2015).

\begin{tabular}{lllll}
\hline Case & Phase lag $\tan (\varepsilon)$ & Scaling $\mu$ & Damping $\delta$ & Celerity $\lambda^{2}$ \\
\hline General & $\lambda /(\gamma-\delta)$ & $\sin (\varepsilon) / \lambda=\cos (\varepsilon) /(\gamma-\delta)$ & $\gamma / 2-4 \chi \mu /(9 \pi \lambda)-\chi \mu^{2} / 3$ & $1-\delta(\gamma-\delta)$ \\
Ideal estuary & $1 / \gamma$ & $\sqrt{1 /\left(1+\gamma^{2}\right)}$ & 0 & 1 \\
\hline
\end{tabular}

This numerical scheme has been shown to be completely non-dissipative but marginally stable when run in a semiimplicit form, which corresponds to weighting factor $(\theta)$ of 0.5 for the unsteady solution. This value represents a half weighting explicit to the previous time step's known solution, and a half weighting implicit to the current time step's unknown solution. However, practically speaking, due to its marginal stability for the semi-implicit formulation, a $\theta$ weighting factor of 0.6 or more is necessary, since the scheme is diffusive only at values of $\theta$ greater than 0.5 . In HEC-RAS, the default value of $\theta$ is 1 . However, the user can specify any value between 0.6 to 1 (Billah et al., 2015).

\subsubsection{Mass transport model}

In the advection-dispersion module, the basic equation is the 1-D advection-dispersion one of a conservative constituent (Brunner, 2010):

$\frac{\partial(A C)}{\partial t}=\frac{\partial}{\partial x}\left[D A \frac{\partial C}{\partial x}\right]-\frac{\partial(Q C)}{\partial x}$,

where $C$ is the salinity concentration $\left(\mathrm{g} \mathrm{L}^{-1}\right), A$ is the crosssectional area of the river $\left(\mathrm{m}^{2}\right), Q$ is the freshwater discharge $\left(\mathrm{m}^{3} \mathrm{~s}^{-1}\right)$ and $D$ is the longitudinal dispersion coefficient $\left(\mathrm{m}^{2} \mathrm{~s}^{-1}\right)$. This module requires output from the hydrodynamics module in terms of discharge, water level, cross-sectional area and hydraulic radius. The advection-dispersion equation is solved using the ULTIMATE QUICKEST explicit upwind scheme (Brunner, 2010). The resultant finite difference solution for Eq. (17) is as follows:

$V^{n+1} C^{n+1}=V^{n} C^{n}+\Delta t$

$\times\left(Q_{\mathrm{up}} C_{\mathrm{up}}^{*}-Q_{\mathrm{dn}} C_{\mathrm{up}}^{*}+\left.D_{\mathrm{dn}} A_{\mathrm{dn}} \frac{\partial C^{*}}{\partial x}\right|_{\mathrm{dn}}-\left.D_{\mathrm{up}} A_{\mathrm{up}} \frac{\partial C^{*}}{\partial x}\right|_{\text {up }}\right)$,

where $C_{n+1}$ is the concentration of a constituent at present time step $\left(\mathrm{g} \mathrm{m}^{-3}\right), C_{n}$ is the concentration of a constituent at previous time step $\left(\mathrm{g} \mathrm{m}^{-3}\right), C_{\text {up }}^{*}$ is the QUICKEST concentration of a constituent at upstream $\left(\mathrm{g} \mathrm{m}^{-3}\right),\left(\partial C^{*} / \partial x\right)_{\mathrm{up}}$ is the QUICKEST derivative of a constituent at upstream $\left(\mathrm{g} \mathrm{m}^{4}\right), D_{\text {up }}$ is the upstream dispersion coefficient $\left(\mathrm{m}^{2} \mathrm{~s}^{-1}\right)$, $V_{n+1}$ : volume of the water quality cell at present time step $\left(\mathrm{m}^{3}\right), V_{n}$ is the volume of the water quality cell at previous time step $\left(\mathrm{m}^{3}\right), Q_{\text {up }}$ is the upstream discharge $\left(\mathrm{m}^{3} \mathrm{~s}^{-1}\right)$ and $A_{\text {up }}$ is the upstream cross-sectional area $\left(\mathrm{m}^{2}\right)$.

Inputs of the transport model are initial and boundary salinity concentrations and the dispersion coefficient (parameter $D$ in Eq. 17).

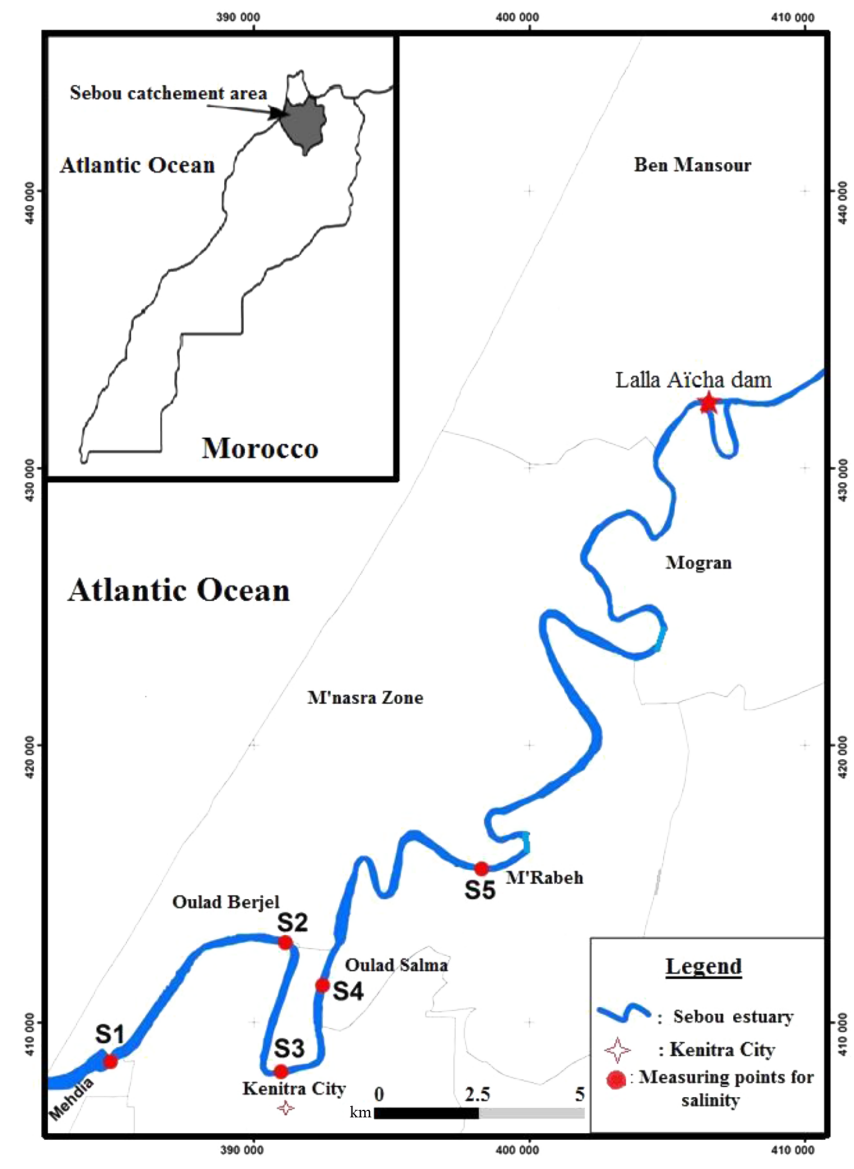

Figure 3. Study area and measurements sites in the Sebou river estuary.

\section{Overview of the Sebou river estuary}

The Sebou is the largest Moroccan river, draining approximately $40000 \mathrm{~km}^{2}$, stretching about $614 \mathrm{~km}$ from its source in the Middle Atlas mountains to the Atlantic Ocean, which represents $6 \%$ of Morocco's total land area (Fig. 3). Kenitra harbor, about $17 \mathrm{~km}$ from the ocean, has commercial traffic, while Mehdia harbor at only $2 \mathrm{~km}$ from the mouth is busy with fishing activities. The flow regime at the level of the Sebou estuary is marked by considerable seasonal and interannual variations. It is under the influence of the tide regime and under the control of many dams (Igouzal and Maslouhi, 2005; Igouzal et al., 2005). During low-flow periods, the hydrodynamic regime is controlled by the Lalla Aïcha dam 
Table 3. Geometric characteristics in the Sebou estuary.

\begin{tabular}{lllllllll}
\hline $\begin{array}{l}\text { Reach } \\
{[\mathrm{km}]}\end{array}$ & $\begin{array}{l}\text { Tidal } \\
\text { conditions }\end{array}$ & $\begin{array}{l}A_{0} \\
{\left[\mathrm{~m}^{2}\right]}\end{array}$ & $\begin{array}{l}B_{0} \\
{[\mathrm{~m}]}\end{array}$ & $\begin{array}{l}h_{0} \\
{[\mathrm{~m}]}\end{array}$ & $\begin{array}{l}a \\
{[\mathrm{~km}]}\end{array}$ & $\begin{array}{l}b \\
{[\mathrm{~km}]}\end{array}$ & $\begin{array}{l}d \\
{[\mathrm{~km}]}\end{array}$ & $\begin{array}{l}T \\
{[\mathrm{~s}]}\end{array}$ \\
\hline \multirow{2}{*}{$0-5$} & Neap-spring & 2300 & 285 & $5.50-5.80$ & 5.24 & 4.40 & -27.45 & 44820 \\
& S-Moon Eclipse & 4900 & 512 & $6.83-7.20$ & 2.84 & 2.01 & -6.88 & 44820 \\
\hline \multirow{2}{*}{$5-35$} & Neap-spring & 1100 & 250 & $4.10-3.10$ & 49 & 34 & -111 & 44820 \\
& S-Moon Eclipse & 3172 & 477 & 5.23 & 51 & 36 & -122.4 & 44820 \\
\hline \multirow{2}{*}{$35-62$} & Neap-spring & 750 & 150 & $3.20-2.00$ & 57 & 60 & 1140 & 44820 \\
& S-Moon Eclipse & 1700 & 316 & 4.24 & 58 & 60 & 1740 & 44820 \\
\hline
\end{tabular}

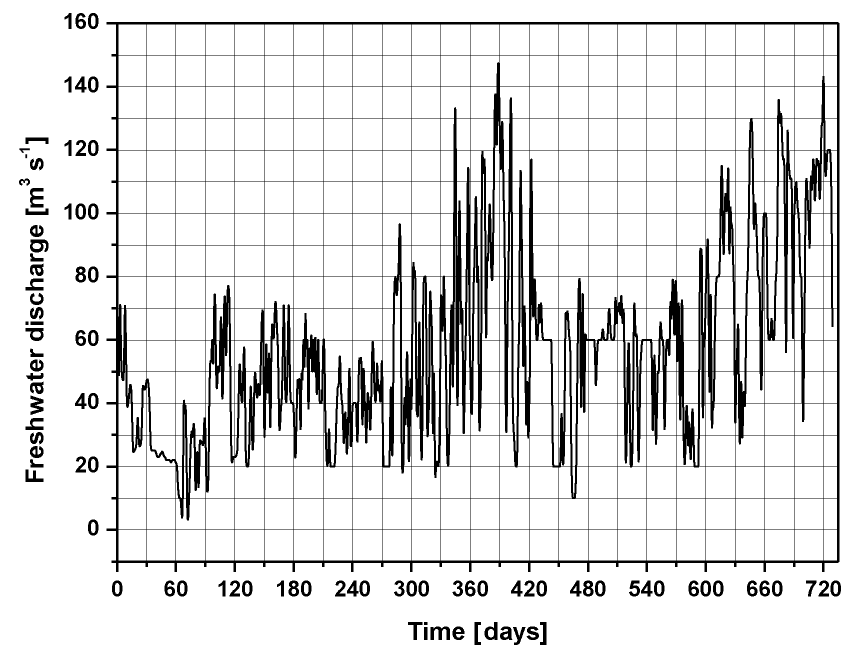

Figure 4. Freshwater discharge release by Lalla Aïcha dam (from 1 January 2014 to 1 January 2016).

situated $62 \mathrm{~km}$ upstream. This dam has been constructed to preserve water for agricultural pumping stations and to prevent the rise of salty water towards these stations. Before the dam construction, excessive salinity reached up to $85 \mathrm{~km}$ upstream (Combe, 1969). Figure 4 shows the flow release by Lalla Aïcha dam from 1 January 2014 to 1 January 2016.

The tidal height varies from 0.9 to $3.10 \mathrm{~m}$ depending on the condition of the tide and the average flow is about $200 \mathrm{~m}^{3} \mathrm{~s}^{-1}$ at the river mouth (Combe, 1966). In addition, the tide near the estuary mouth is mainly semi-diurnal with a $44820 \mathrm{~s}$ tidal cycle (Haddout et al., 2014) and is a meso-/micro-tidal estuary. The topography of the Sebou estuary is presented in Fig. 5. Figure 5 shows the shapes of cross-sectional area, channel width and depth during neap-spring and supermoon total lunar eclipse tides. The cross-sectional area and width are plotted directly from bathymetric data, and the water depth represents the ratio of these two geometric values. The bathymetric data were provided by local water authorities (i.e., ANP: National Agency of Ports and the Water Services of Kenitra town).
The entire estuary can be divided into two reaches with different convergence length for cross-sectional area, width and depth. The first inflection point is located at $x=$ $5 \mathrm{~km}$ (between the river mouth (Mehdia) and Kenitra). The second inflection point is located at $x=35 \mathrm{~km}$ (between Oulad Salma and M'Rabeh), where the convergence length switches and the estuary becomes more riverine. Geometrical characteristics along the Sebou estuary are summarized in Table 3, with the cross-sectional area; width and depth are well described by exponential functions (Fig. 5).

The convergence length is shorter in the seaward reaches ( $x=0-5 \mathrm{~km}$ and $x=5-35 \mathrm{~km}$ ) where the tidal influence is dominant over the river flow, compared with that in the landward reach $(x=35-62 \mathrm{~km})$ where the influence of river flow becomes important). The depth gradually increases from Lalla Aïcha dam to seaward, while the cross-sectional area and width remains roughly constant.

\section{Field data interpretation}

In this study, five locations: Mehdia, Oulad Berjel, Kenitra, Oulad Salma, and M'Rabeh along the Sebou estuary are chosen for salt measurements (Fig. 6) during $12 \mathrm{~h}$ of 28 September 2015 (supermoon total lunar eclipse day). A W-P600 conductivity meter is used in each location. The salinity can be expressed in parts per thousand (ppt or $\mathrm{gL}^{-1}$ ) and the average value in the ocean is $35 \mathrm{~g} \mathrm{~L}^{-1}$. The period of measurements included the LWS, TA and HWS situations (HWS and LWS correspond to periods when water velocity changes its directions and becomes nearly zero).

The maximum and minimum salinity curves at HWS and LWS were thus observed, representing the envelopes of the salinity variation during tidal cycle. Figure 6 shows vertically averaged salinity concentration measurements conducted at the five locations, during $12 \mathrm{~h}$ with $12 \mathrm{~min}$ interval. A maximum salinity concentration is recorded during high tides with $35.5 \mathrm{~g} \mathrm{~L}^{-1}$ at the river mouth, $32.7 \mathrm{~g} \mathrm{~L}^{-1}$ at Oulad Berjel, $30 \mathrm{~g} \mathrm{~L}^{-1}$ at Kenitra, $1.2 \mathrm{~g} \mathrm{~L}^{-1}$ at Oulad Salma and $0.9 \mathrm{~g} \mathrm{~L}^{-1}$ at $\mathrm{M}^{\prime}$ Rabeh. A minimum salinity concentration is recorded during low tides with $17.5 \mathrm{~g} \mathrm{~L}^{-1}$ at the river mouth and less than $1 \mathrm{~g} \mathrm{~L}^{-1}$ in the other four locations. 

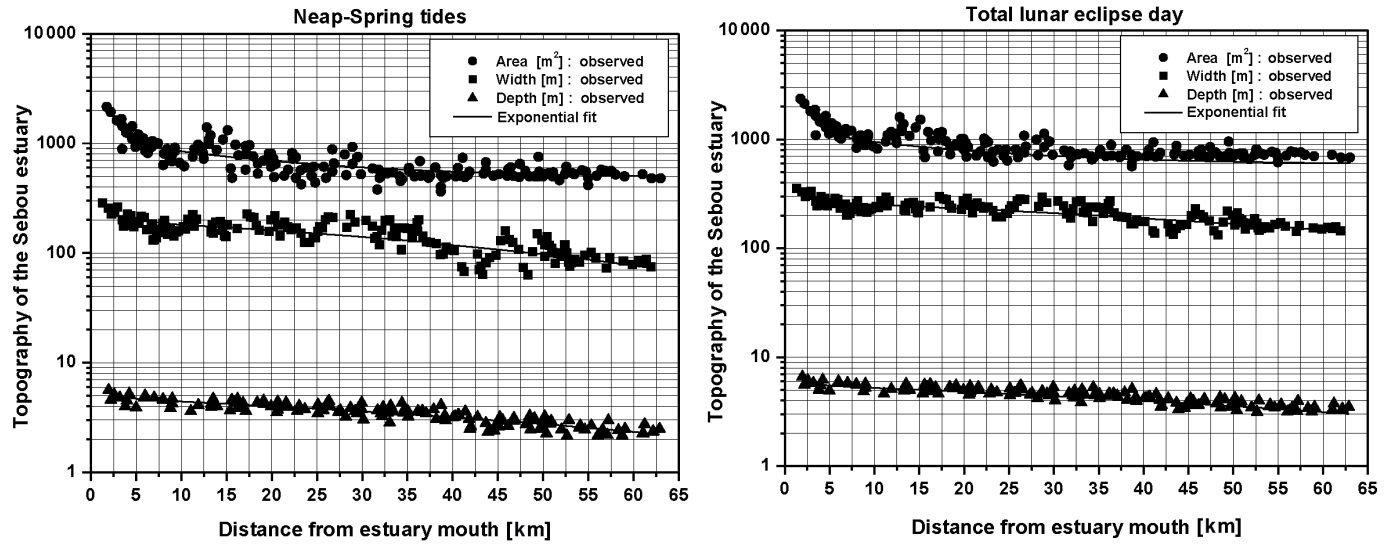

Figure 5. Geometry of the Sebou estuary, showing the cross-sectional area $A\left(\mathrm{~m}^{2}\right)$, the width $B(\mathrm{~m})$ and the estuary depth $h(\mathrm{~m})$ during neap-spring and total lunar eclipse tides.

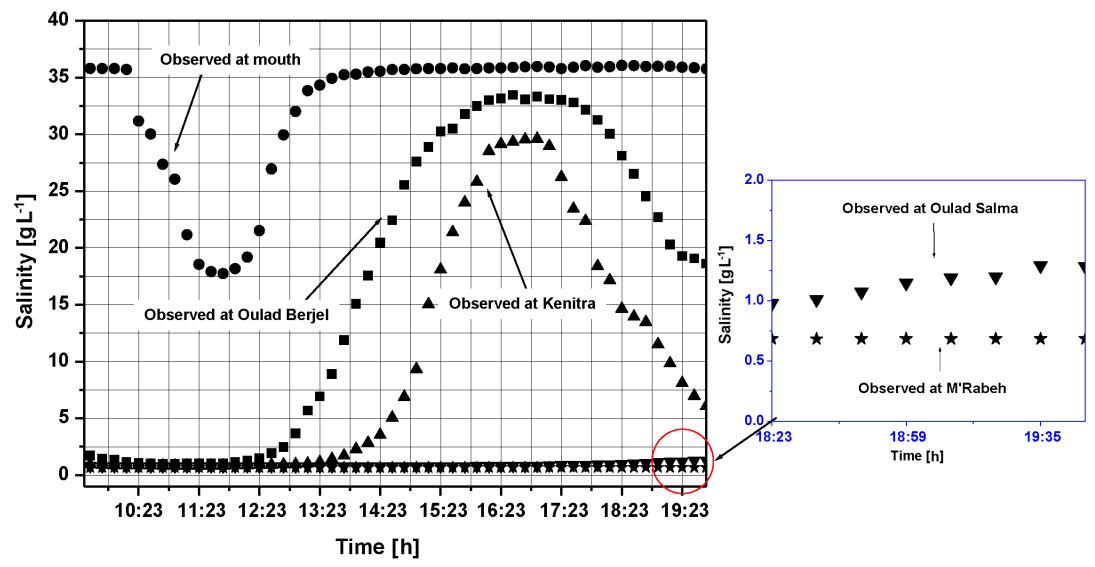

Figure 6. Salinity evolution in the Sebou river estuary during $12 \mathrm{~h}$ (surveyed on 28 September 2015).

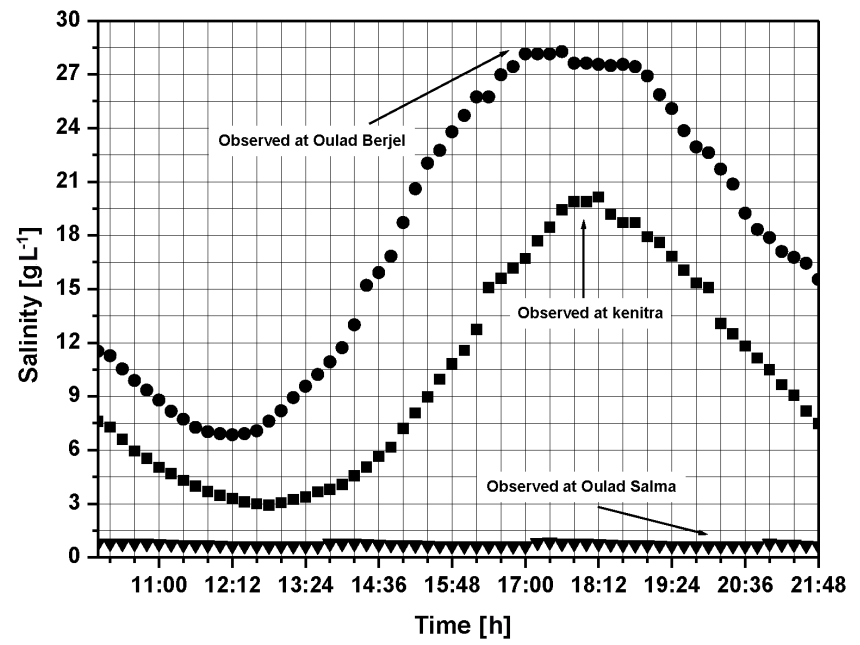

Figure 7. Salinity evolution in the Sebou river estuary during spring tide (surveyed on 11 February 2016).
Furthermore, Fig. 7 shows vertically averaged salinity concentration measurements at normal situation during spring tide in three locations (Oulad Berjel, Kenitra and Oulad Salma). A maximum salinity concentration is recorded during high tides with $28.5 \mathrm{~g} \mathrm{~L}^{-1}$ at Oulad Berjel, $19.8 \mathrm{~g} \mathrm{~L}^{-1}$ at Kenitra and $0.9 \mathrm{~g} \mathrm{~L}^{-1}$ at Oulad Salma. A minimum salinity concentration is recorded during low tides with $5 \mathrm{~g} \mathrm{~L}^{-1}$ at Oulad Berjel and less than $3 \mathrm{~g} \mathrm{~L}^{-1}$ in the other two locations.

The mixing mechanisms in estuaries are guided by tidal dynamics, the dispersion mechanisms and the amount of freshwater discharge from the river estuary. Dispersion includes longitudinal mixing, that takes place by mass traveling in streamlines at different velocities (Nylén and Ramel, 2012) and vertical mixing. Earlier measurements on Sebou estuary (Haddout et al., 2015) has shown vertical salinity and temperature stratification, essentially for locations near the estuary mouth (Mehdia, Oulad Berjel and Kenitra), classifying Sebou estuary as a partially mixed river. In addition, 
Table 4. Calibrated parameters for the hydrodynamic model of the Sebou estuary.

\begin{tabular}{llllll}
\hline \multirow{2}{*}{ Reach $[\mathrm{km}]$} & \multicolumn{4}{c}{ Storage width ratio $r_{\mathrm{S}}(-)$} & \multirow{2}{*}{ Manning-Strickler friction $K_{\mathrm{S}}\left(\mathrm{m}^{1 / 3} \mathrm{~s}^{-1}\right)$} \\
\cline { 2 - 5 } & Spring & Moderate & Neap & Eclipse day & \\
\hline $0-5$ & 1.20 & 1.30 & 1.30 & 1.01 & 67 \\
$5-35$ & 1.20 & 1.30 & 1.30 & 1.01 & 65 \\
$35-62$ & 1.40 & 1.40 & 1.40 & 1.30 & 41 \\
\hline
\end{tabular}

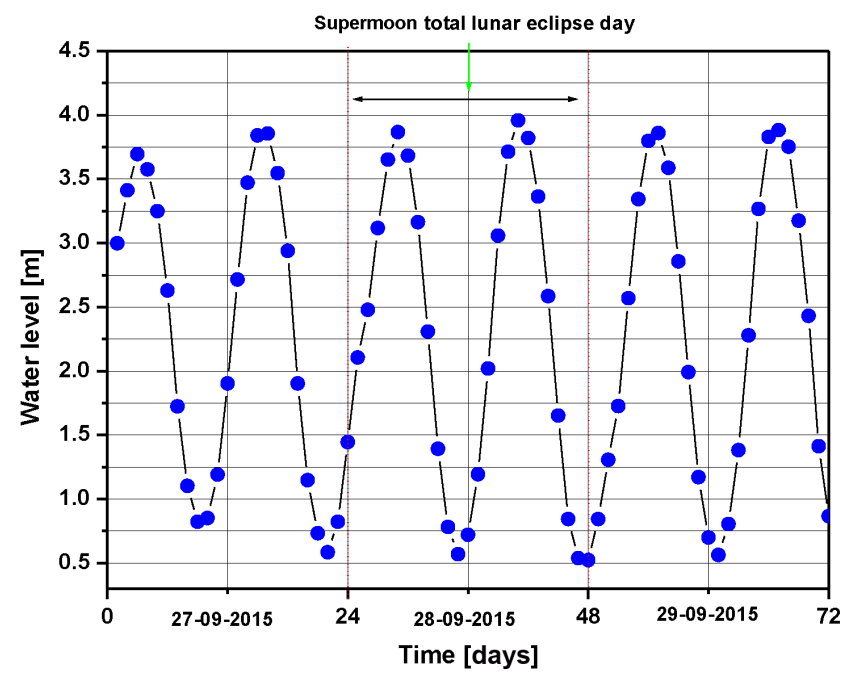

Figure 8. Water level measurements at Kenitra location from 27 to 29 September 2015.

Fig. 8 shows water level measurements at the Kenitra location from 27 to 29 September 2015.

The water level drops in the low tide and then rises and peaks with the high tide to $4 \mathrm{~m}$ at supermoon total lunar eclipse day (less than $3.2 \mathrm{~m}$ in normal situation). This indicates the supermoon total lunar eclipse influence on the estuary hydrodynamic regime.

\section{Results and analysis}

In this paper, the analytical (tidal propagation and salt intrusion) and numerical models introduced in the previous sections are applied to the Sebou estuary to evaluate the supermoon total lunar eclipse effect on salinity distribution.

\subsection{Application of the coupled salt intrusion analytical model}

To turn the steady-state model into a predictive model, semiempirical relations (Eq. 6) are required that relate the two optimization parameters $K$ and $D_{1}$ to hydrodynamic and geometrical bulk parameters. These bulk parameters are dimensionless numbers composed of geometrical $\left(a, b, A_{0}, B_{0}, h_{0}\right)$, hydrological $(Q)$ and hydraulic $\left(H, E, C_{z}, v, \eta\right)$ parameters that influence the process of mixing and advection. An analytical hydrodynamic model for tidal wave propagation is used to reproduce the main tidal dynamics along the estuary axis and subsequently for predicting the main parameters (Van der Burgh's coefficient $K$, dispersion coefficient $D_{1}$ and tidal excursion $E$ ) that influence the salt intrusion process, during supermoon total lunar eclipse day, of the Sebou estuary.

Field measurements of salt intrusion along the Sebou estuary axis, which were conducted at the 7-18-27 May 2015 (covering a spring-neap cycle) and at the 28th supermoon total lunar eclipse day, are used to test the predictive method. Each tidal cycle consists of two HWS and two LWS salinity observations, which corresponds to the tidal wave periods. The hybrid (hydrodynamic) model presented in Sect. 1 was calibrated during 7-18-27 May 2015 and at supermoon total lunar eclipse day. The calibrated parameters, the ManningStrickler friction coefficient $K_{s}$ and the storage width ratio $r_{\mathrm{s}}$, are presented in Table 4 . It is worth noting that the storage width ratio $r_{\mathrm{s}}$ is different in the seaward reaches for various tidal situations. It is important to point out that the model uses a variable depth in order to account for variations of the estuarine sections along the channel. Figure 9a shows the longitudinal computations of tidal amplitude and traveling time along the Sebou estuary for the selected periods (representing the spring tide, the moderate tide, the neap tide and supermoon total lunar eclipse day). The agreement between analytically computed and observed tidal amplitude and traveling time for HW and LW is good. Furthermore, these results show that the difference between supermoon total lunar eclipse day and spring-neap situation is very remarkable. Additionally, Fig. 9b shows the velocity amplitude and damping number at supermoon total lunar eclipse, which suggests that the hybrid model proposed by Cai et al. (2012a, 2014a) can well reproduce the tidal dynamics and velocity amplitude with a significant range of dam discharges.

Based on the hydrodynamic parameters (e.g., tidal amplitude and velocity amplitude) from the hybrid (hydrodynamic) model, it is possible to estimate the main parameters that determine the salinity intrusion from predictive Eqs. (8) and (9) at the inflection point. In most estuaries, there usually exists an inflection point near the mouth, where the geometry changes (e.g., Gisen et al., 2015b). Moreover, the Van Der Burgh's $(K)$ and dispersion $\left(D_{1}\right)$ coefficients are initially estimated by Eqs. (8) and (9). However, due to the 
(a)
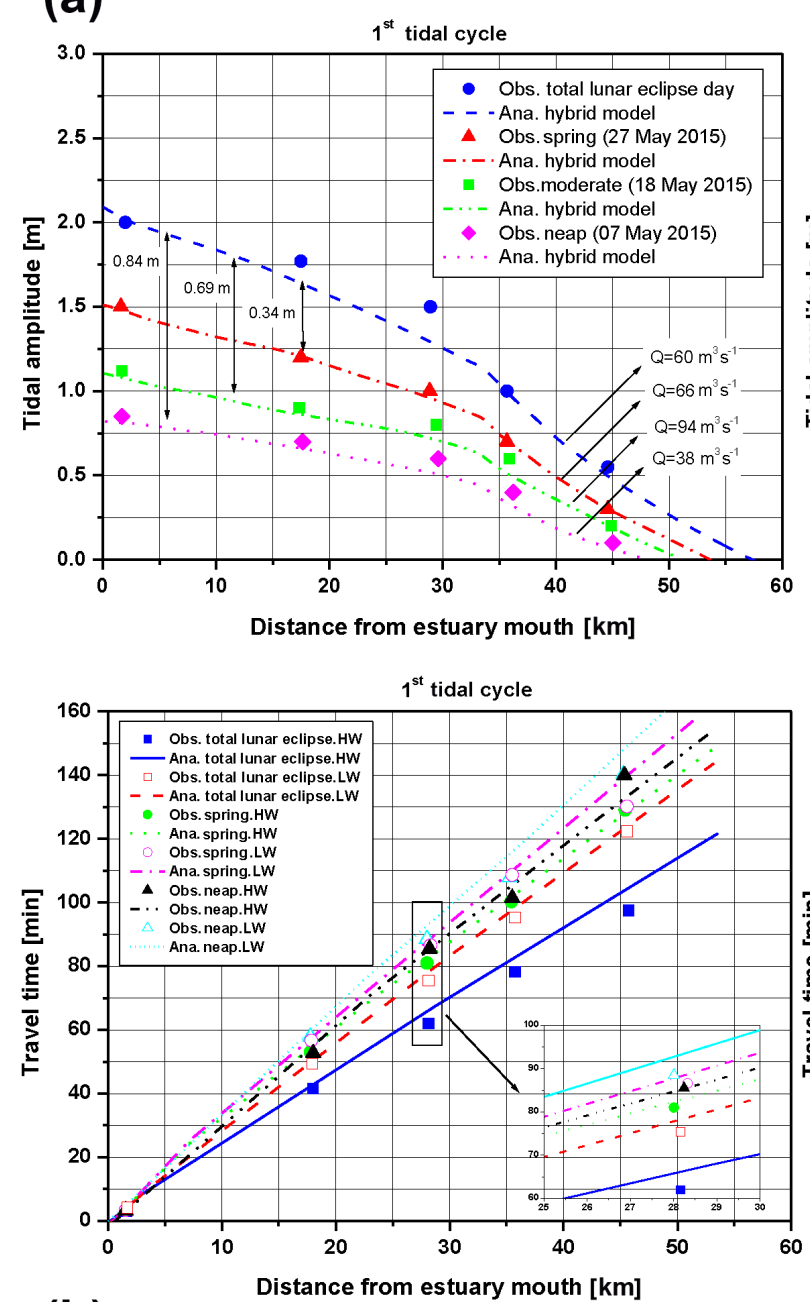

(b)

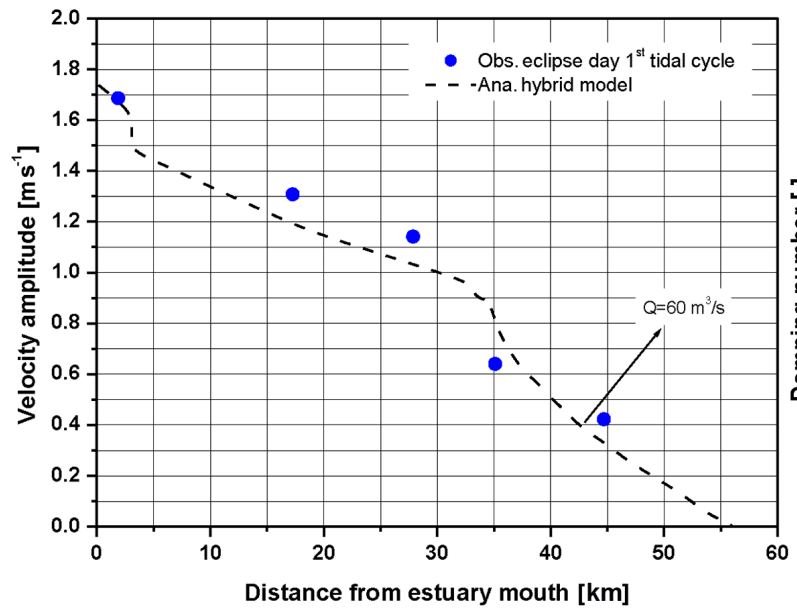

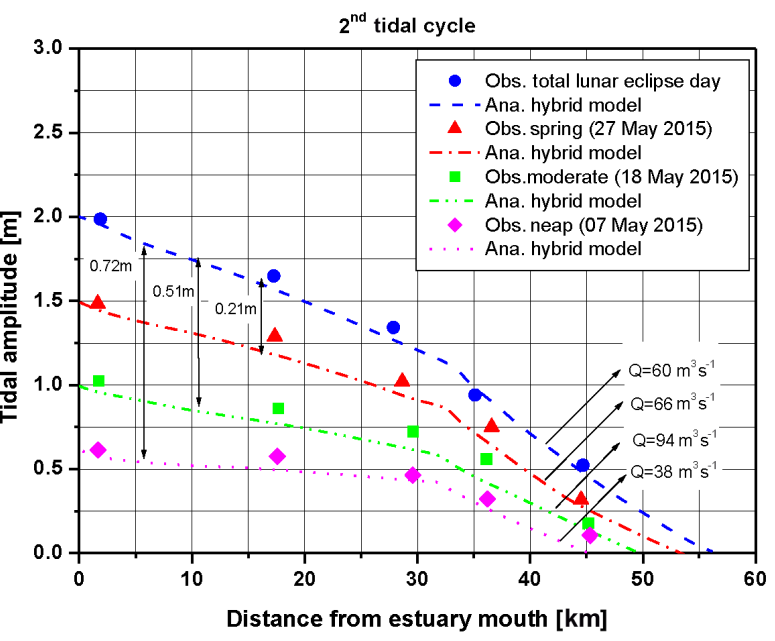
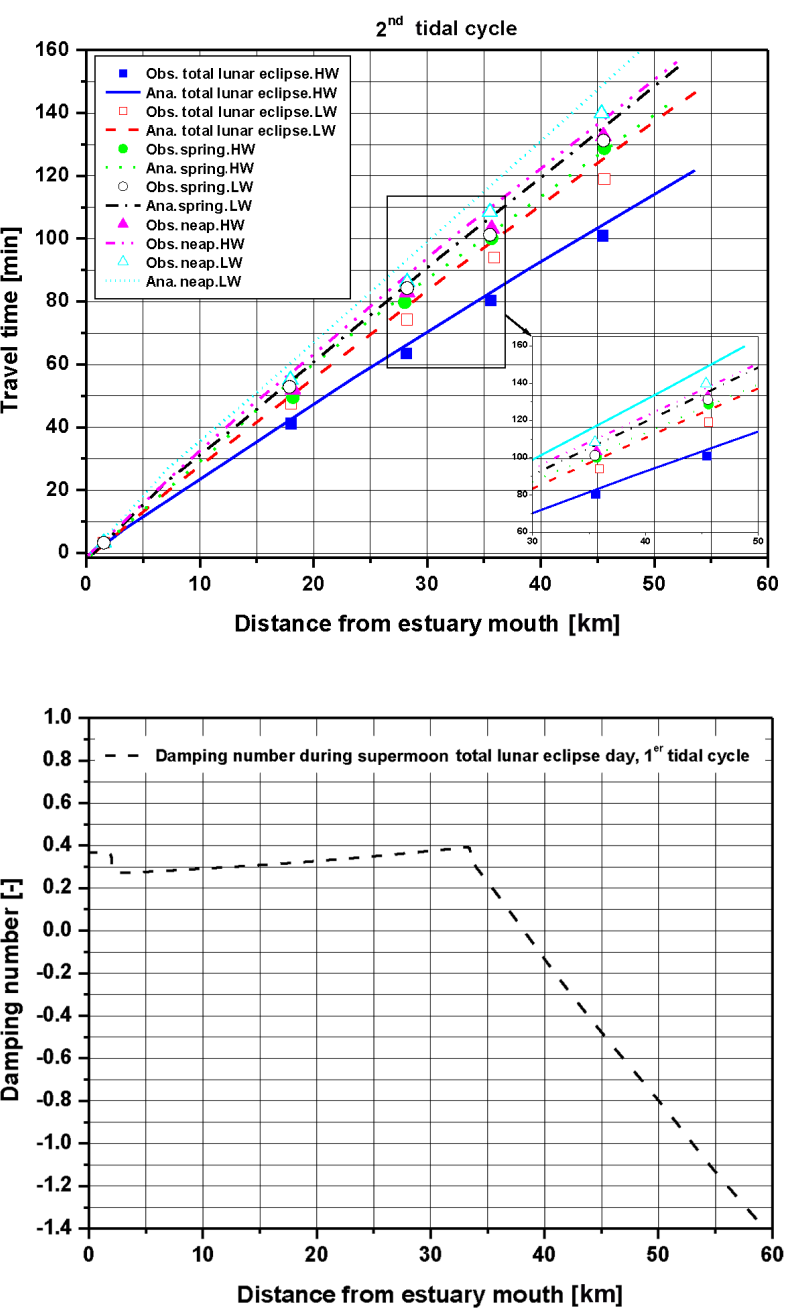

Figure 9. (a) Analytically computed tidal amplitude and traveling time along the Sebou estuary at supermoon total lunar eclipse day. (b) Analytically computed velocity amplitude and damping number along the Sebou estuary at supermoon total lunar eclipse day. 

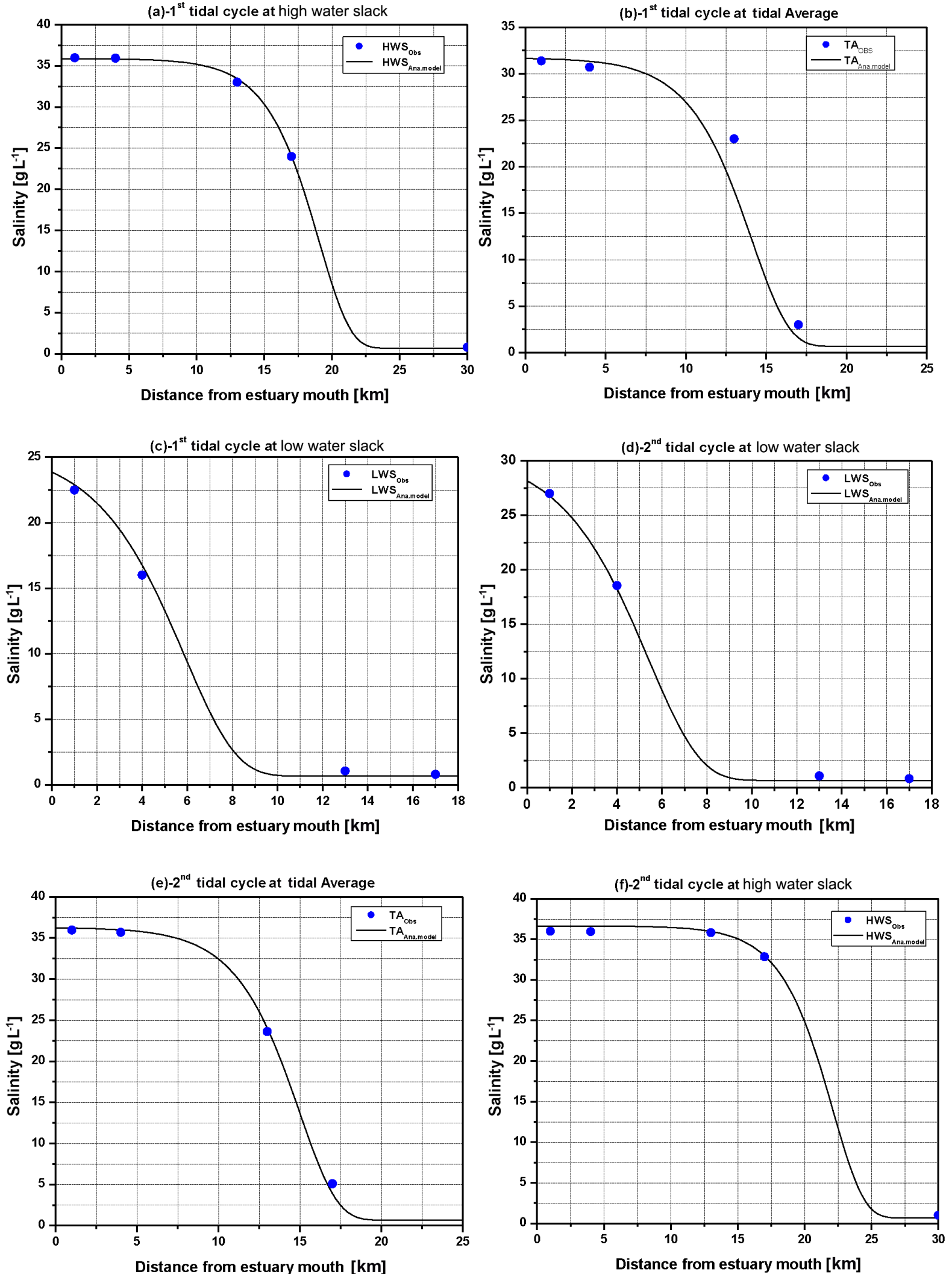

Figure 10. Observed and analytically computed longitudinal salinity distribution along the Sebou estuary (surveyed on 28 September 2015) during 1st cycle $(\mathbf{a}, \mathbf{b}, \mathbf{c})$ at LWS, TA and HWS, and 2nd cycle $(\mathbf{d}, \mathbf{e}, \mathbf{f})$ at LWS TA and HWS. 

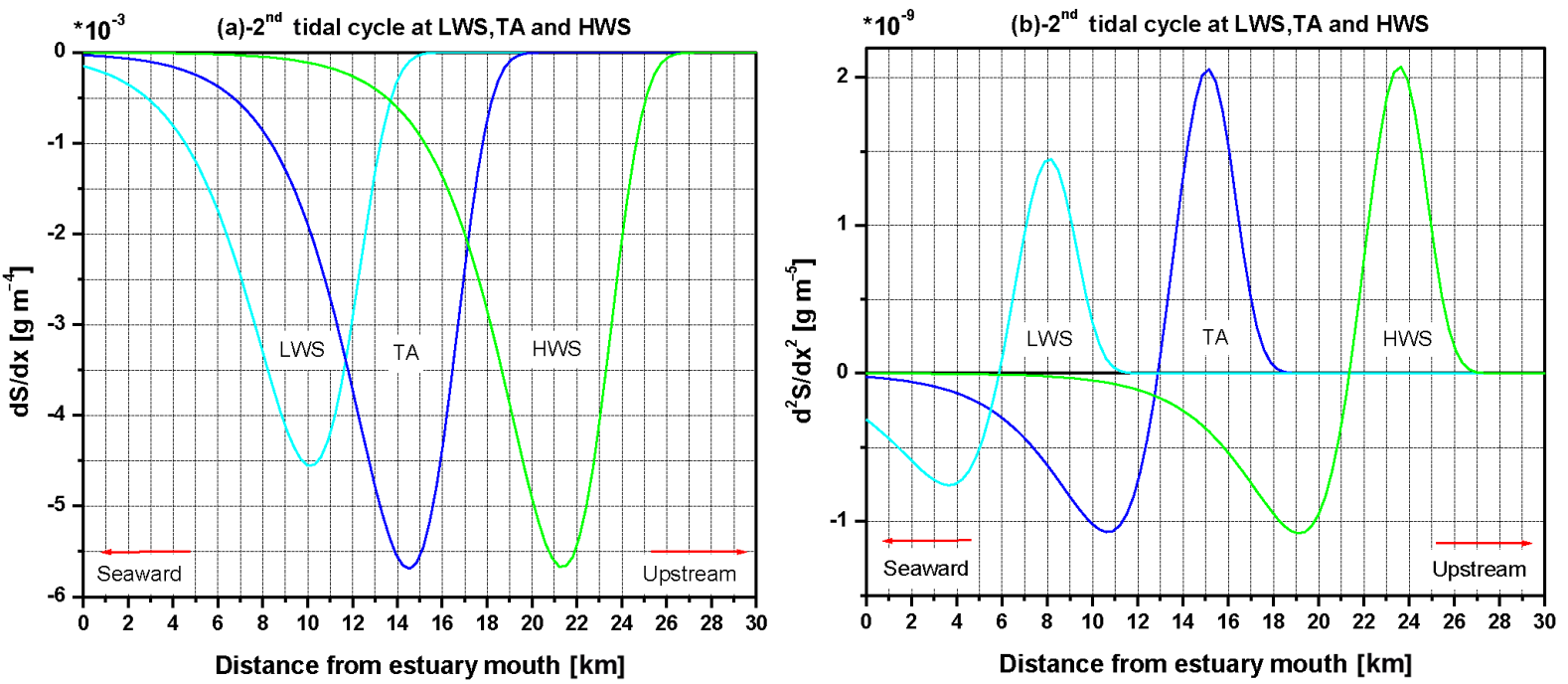

Figure 11. Longitudinal variation of salinity gradient (a) and curvature (second derivative) (b) along the Sebou estuary axis.

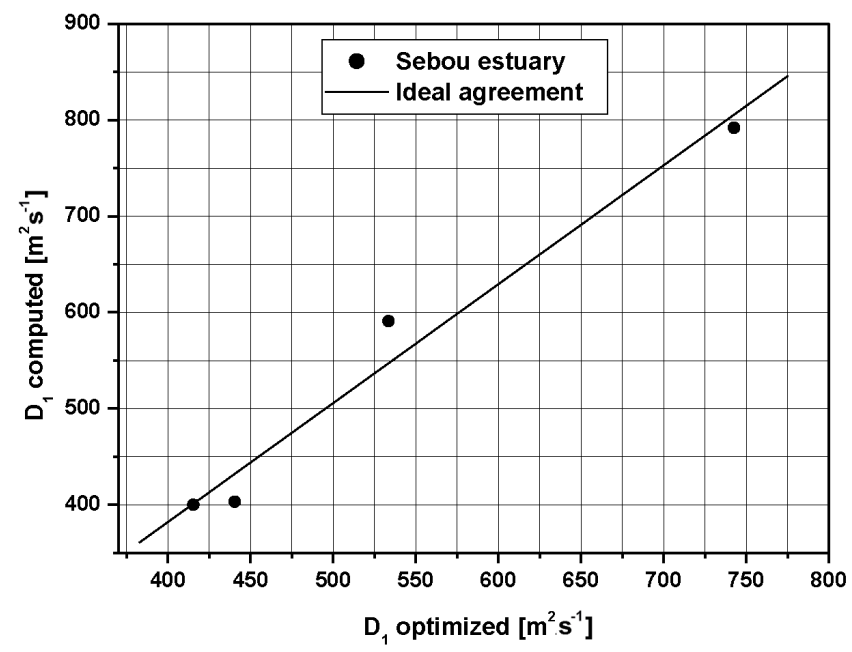

Figure 12. Comparison of computed and optimized dispersion $D_{1}$ coefficient at HWS in the spring-neap and the supermoon total lunar eclipse day tides.

large uncertainty of these predictive equations, the $K$ and $D_{1}$ estimations should be refined on the basis of salinity measurements. The optimization process of $K$ and $D_{1}$ has been carried out using the Levenberg-Marquardt nonlinear minimization method (Marquardt, 1963). In this method, the following objective function $\phi$ is minimized during the parameters optimization process:

$\min \phi\left(\left(K, D_{1}\right), S\right)=\frac{\sum_{i=1}^{m}\left(S_{i}-S_{i}^{+}\left(K, D_{1}\right)\right)^{2}}{m, \sigma_{S}^{2}}$,

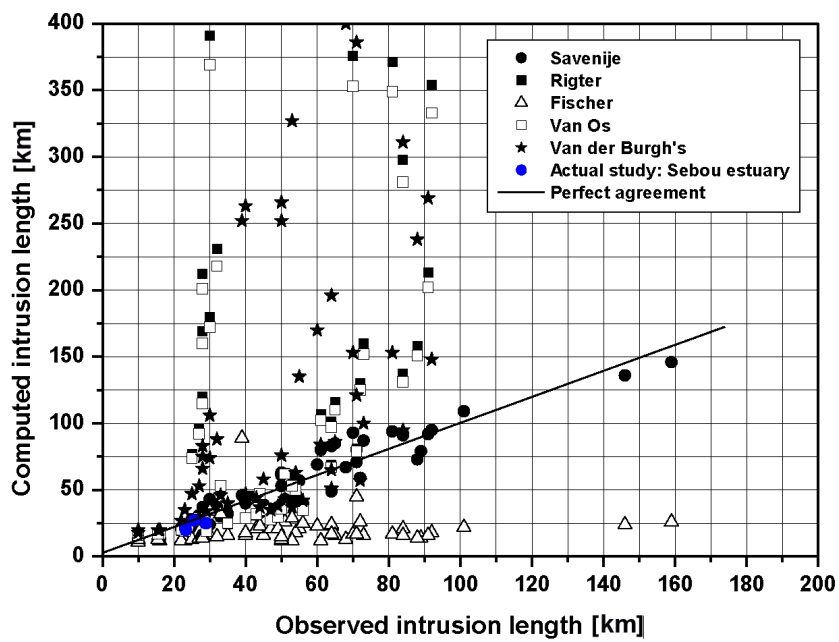

Figure 13. Salt intrusion lengths computed against observed lengths (at HWS) for different predictive formulae found in the literature (Savenije, 2005) compared with results of the actual study on Sebou estuary.

where $S_{i}$ and $S_{i}^{+}$are the measured and predicted salinity, $\sigma_{S}^{2}$ are variance of the measured salinity, $m$ is number of observation.

The Levenberg-Marquardt algorithm adaptively varies the parameter updates between the gradient descent update and the Gauss-Newton update.

Values of the optimized parameters are summarized in Table 5 (at HWS), where the dispersion coefficient at the estuary mouth $D_{0}$ can be obtained by substituting $D_{1} ; x_{1}$ and $K$ into Eq. (4). It can be shown that the estimated values of the parameters $D_{1}$ and $K$ are very close to their reference values (Eqs. 8 and 9). This indicates that the predictive equations 
(a)

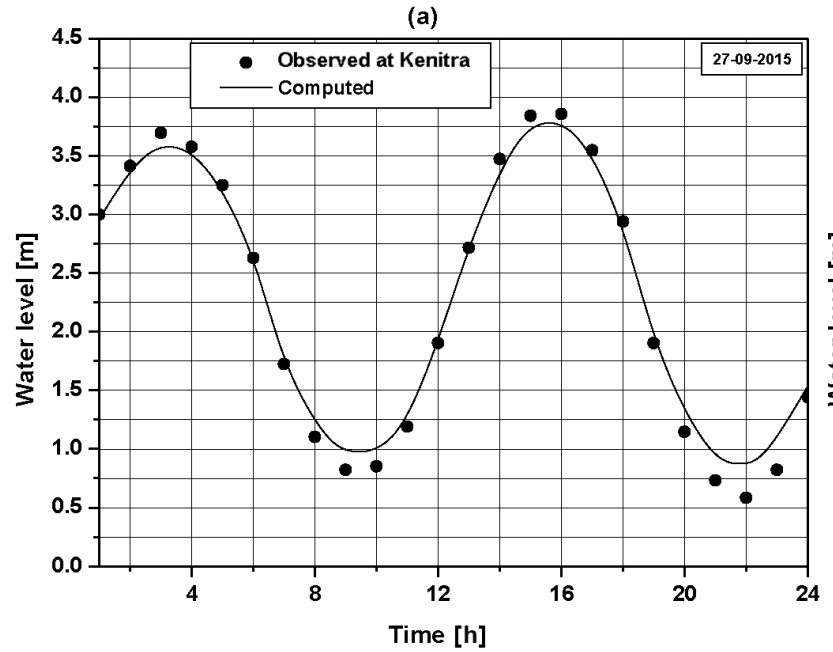

(b)

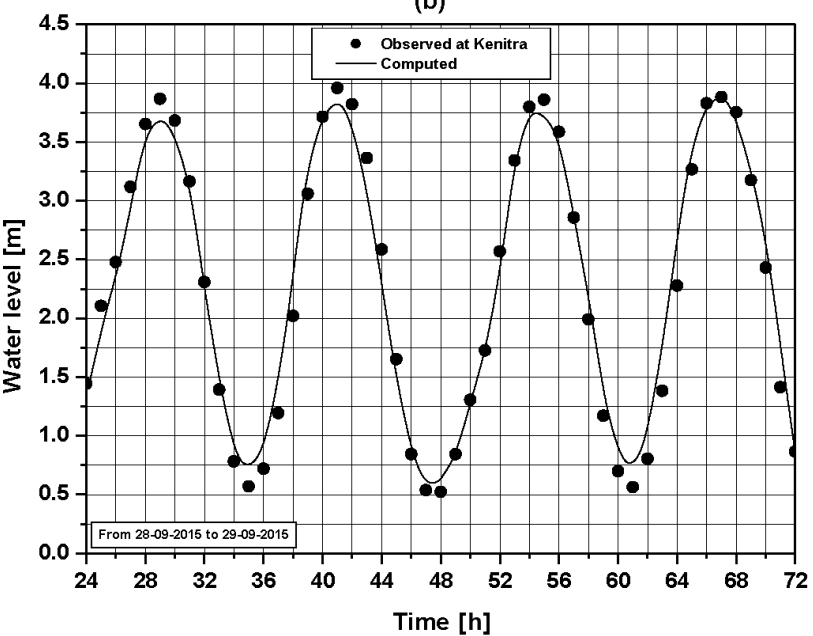

Figure 14. Water level comparisons at Kenitra location in calibration (a) and validation (b).

(a)

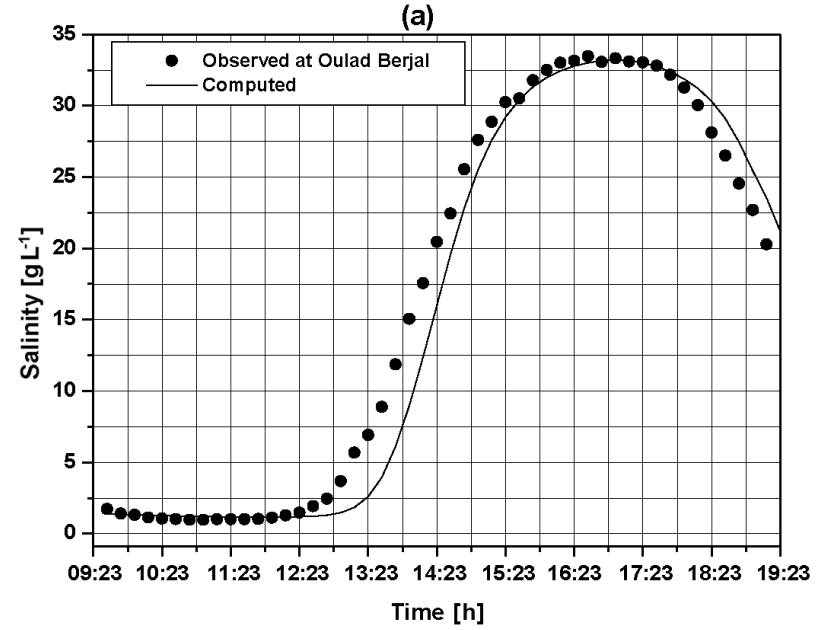

(b)

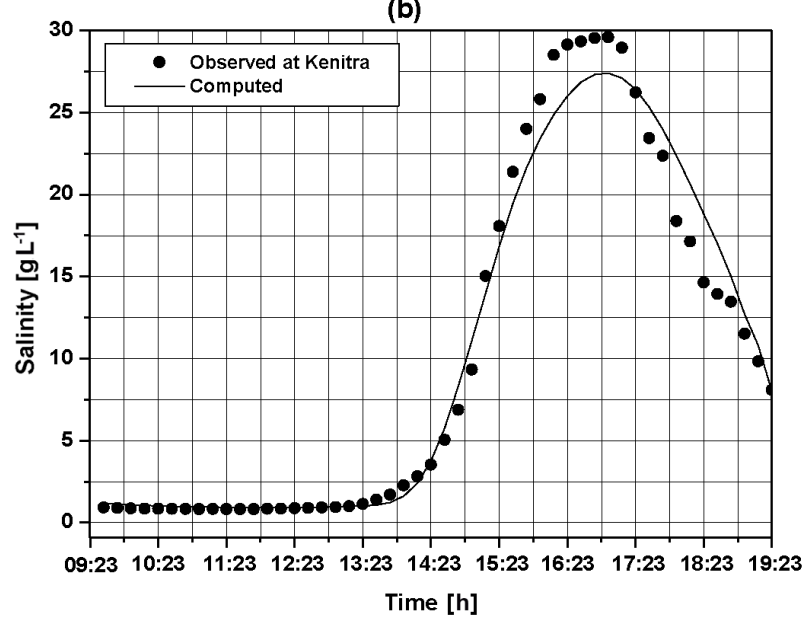

(c)

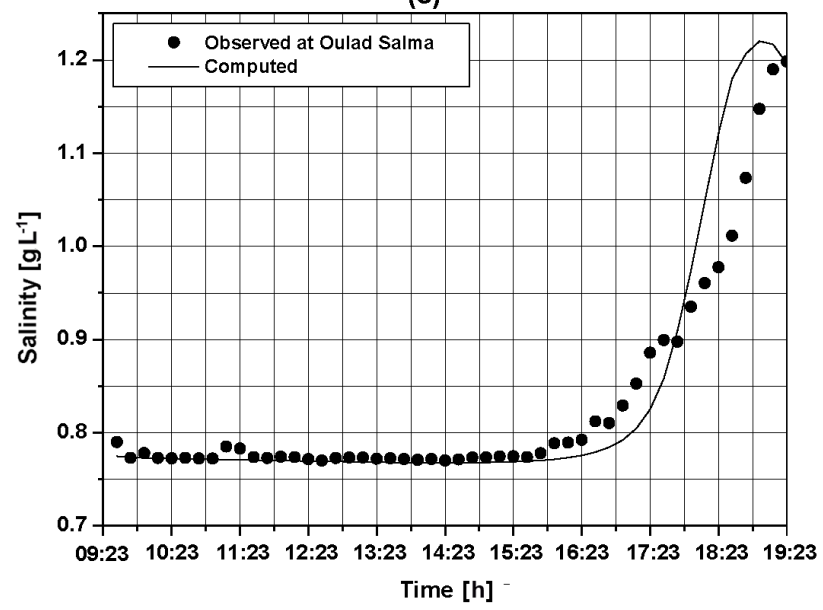

Figure 15. Salinity comparisons at Oulad Berjel (a), Kenitra (b) and Oulad Salma (c) in calibration.

developed by Savenije (1993a, 2012) and revised by Gisen et al. (2015b) are appropriate to be applied in getting a first estimate of $D_{1}$ and $K$ as starting values for the optimization process. At each tidal condition (HWS, LWS, and TA), the 
Table 5. Salinity distribution data showing the salinity at the mouth $\left(S_{0}\right)$, tidal excursion $(E)$, Richardson number $\left(N_{\mathrm{R}}\right)$, dispersion coefficient at high water slack, Van Der Burgh's coefficient $(K)$ and salt intrusion length at high water slack $(L)$. S.M. stands for supermoon.

\begin{tabular}{llllllllll}
\hline Tidal conditions & $S_{0}$ & $E$ & $\begin{array}{l}N_{\mathrm{R}} \\
{\left[\mathrm{g} \mathrm{L}^{-1}\right]}\end{array}$ & $\begin{array}{l}D_{1}^{\mathrm{HWS}}{ }_{\text {Computed }} \\
{[\mathrm{km}]}\end{array}$ & $\begin{array}{l}\left.D_{1}^{\mathrm{HWS}} \mathrm{m}^{2} \mathrm{~s}^{-1}\right] \\
{\left[\mathrm{m}^{2} \mathrm{~s}^{-1}\right]}\end{array}$ & $\begin{array}{l}K_{\text {Computed }} \\
{[-]}\end{array}$ & $\begin{array}{l}K_{\text {Optimzed }} \\
{[-]}\end{array}$ & $\begin{array}{l}L_{\text {Comp }} \\
{[\mathrm{km}]}\end{array}$ & $\begin{array}{l}L_{\text {Obs }} \\
{[\mathrm{km}]}\end{array}$ \\
\hline S.M. eclipse (1st at HWS) & 35.8 & 12.31 & 0.047 & 533.61 & 590.90 & 0.18 & 0.20 & 29.0 & 25.0 \\
S.M. eclipse (2nd at HWS) & 35.8 & 11.91 & 0.060 & 742.59 & 792.02 & 0.18 & 0.20 & 25.6 & 27.0 \\
Spring HWS & 35.0 & 06.50 & 0.305 & 440.48 & 403.25 & 0.16 & 0.15 & 23.1 & 21.5 \\
Neap HWS & 34.5 & 08.00 & 0.150 & 415.40 & 400.00 & 0.15 & 0.15 & 23.3 & 20.0 \\
\hline
\end{tabular}

optimized values of $D_{1}$ are greater that initial estimated values, whereas the optimized values of the coefficient $K$ have remained constant and equal to 0.20 for all tidal conditions on the supermoon total lunar eclipse day. Also, in normal situations Haddout et al. (2015) found a value of $K=0.15$, which is relatively small compared to the value of $K=0.20$ during eclipse day.

We attribute this difference to the dominance of tidal mixing in the Sebou estuary for the eclipse period. Because the optimized value of $K$ remained constant, fitted salinity curves were more sensitive to the dispersion coefficient $D$ at HWS, LWS, and TA (Haddout et al., 2015). Results of the axial salinity analysis at HWS, TA and LWS are plotted in Fig. 10. On the whole, it can be said that the analytical salt intrusion model performs well in representing the salinity distribution in the Sebou estuary (surveyed on 28 September 2015).

Additionally, salt intrusion exhibits three distinct tendencies: a dome shape at HWS and TA, a recession and bell shapes at LWS (see Appendix A). These three salinity shapes were observed during the eclipse day.

Furthermore, in a positive estuary, the salinity gradient is always negative due to the decreasing salinity in the landward direction as is the case for the Sebou river estuary (Fig. 11a). The dome shaped intrusion curves have a negative curvature in the seaward part of the estuary. As water level increases, the position of the maximum salinity gradient moves towards the estuary seaward, after which it has a dome shape with monotonous increasing of the salinity gradient. In addition, Fig. 11b shows curves of the second derivative of salinity gradient.

Additionally, the scatter plot of the computed vs. optimized results for the dispersion coefficient at high water slack is shown in Fig. 12.

\section{The predictive model compared to other methods}

This salinity intrusion model has been applied in different estuaries all over the world and by several methods (e.g. Van den Burgh, 1972; Rigter, 1973; Fischer, 1974; Van Os and Abraham, 1990; Savenije, 1993a, 2005; see Appendix B).

Figure 13 shows the computed salt intrusion lengths against observed lengths (at HWS) with data specific to Sebou estuary compared to different predictive formulae found in the literature. We observe that the Savenije solution for salt intrusion lengths fits very well with the observed data compared to all others solutions. The results of Savenije model are considered most accurate.

\subsection{Numerical modeling of salinity distribution}

\subsubsection{Hydrodynamic model}

The hydrodynamic regime was first studied and modeled in HEC-RAS. Outputs from the hydrodynamic model (velocity and water level evolution) were used in the salt transport study. The final resolution of hydrodynamic model Eqs. (14) and (15) requires spatial discretization of the study area. The river reach $(62 \mathrm{~km})$ was discretized into 203 grids with a length varying between 58 and $996 \mathrm{~m}$ (Haddout et al., 2016). Data on cross-sectional areas from the ANP and other sources were used. The upstream boundary at the Lalla Aïcha dam was given values of discharge as a function of time from 27 to 29 September 2015. Also, the seaward boundary at the mouth was given values of the water level as a function of time.

The factor $n_{0}$ Eq. (16) is evaluated from granulometric measurements that were carried out from upstream to seaward in the studied reach. The others coefficients were evaluated from observations of the river in aerial photos, from the cross-sectional areas and available photos, and from field visits.

The hydrodynamic model has been calibrated and validated using data from 27 to 29 September 2015. The calibrated parameter is Manning's roughness in the estuary. The calibration and validation are performed using the water level data at Kenitra location. The 27 September 2015 day has been used for calibration. The roughness coefficients were adjusted by a trial and error approach until the simulated and observed water levels were satisfactory.

Figure 14a shows the comparison of the simulated water level at Kenitra location with the observed data where the water levels are measured based on the datum of the ANP. For the model validation, water levels during 28 and 29 September 2015 have been used. Figure 14b shows good correspondence between the observed and simulated water levels at the Kenitra location. 
Table 6. Statistical indicators of analytical hydrodynamic model performance during the supermoon total lunar eclipse day.

\begin{tabular}{llllll}
\hline $\begin{array}{l}\text { Statistical indicators of hybrid } \\
\text { model during eclipse day }\end{array}$ & $\begin{array}{l}\text { RMSE } \\
{[\mathrm{m}, \mathrm{min}]}\end{array}$ & $\begin{array}{l}\text { ABSERR } \\
{[\mathrm{m}, \mathrm{min}]}\end{array}$ & $\begin{array}{l}\text { EF } \\
{[-]}\end{array}$ & $\begin{array}{l}R^{2} \\
{[-]}\end{array}$ & $\begin{array}{l}\text { PBIAS } \\
{[\%]}\end{array}$ \\
\hline Tidal amplitude (1st and 2nd) & $0.42-0.49$ & $0.37-0.53$ & $0.79-0.89$ & $0.91-0.92$ & $1.42-1.7$ \\
Travel time at HW (1st and 2nd) & $0.50-0.65$ & $0.32-0.44$ & $0.88-0.94$ & $0.89-0.93$ & $1.01-1.1$ \\
Travel time at LW (1st and 2nd) & $0.55-0.61$ & $0.30-0.47$ & $0.97-0.95$ & $0.95-0.97$ & $0.98-1.0$ \\
\hline
\end{tabular}

Table 7. Statistical indicators of analytical salinity intrusion model performance at HWS during the supermoon total lunar eclipse day.

\begin{tabular}{llllll}
\hline $\begin{array}{l}\text { Statistical indicators of salinity model } \\
\text { during supermoon eclipse day }\end{array}$ & $\begin{array}{l}\text { RMSE } \\
{\left[\mathrm{g} \mathrm{L}^{-1}\right]}\end{array}$ & $\begin{array}{l}\text { ABSERR } \\
{\left[\mathrm{g} \mathrm{L}^{-1}\right]}\end{array}$ & $\begin{array}{l}\mathrm{EF} \\
{[-]}\end{array}$ & $\begin{array}{l}R^{2} \\
{[-]}\end{array}$ & $\begin{array}{l}\text { PBIAS } \\
{[\%]}\end{array}$ \\
\hline 1st (at HWS) & 0.83 & 0.70 & 0.90 & 0.90 & 1.36 \\
2nd (at HWS) & 0.73 & 0.81 & 0.94 & 0.93 & 2.30 \\
\hline
\end{tabular}

\subsubsection{Salt transport model}

The salinity model has been calibrated by systematically adjusting the values of the dispersion coefficient to achieve an acceptable match between the measured salinity and the corresponding values computed by the 1-D advectiondispersion model. The dispersion coefficient was modified to the same degree along the studied reach because we assumed that the sources of errors involved in its evaluation are identical for all the grids. The calibrated values of the coefficient " $D$ " ranges from 500 to $900 \mathrm{~m}^{2} \mathrm{~s}^{-1}$ along the river. Figure 15 shows the comparison of the observed and computed salinity at three locations (Oulad Berjel, Kenitra and Oulad Salma) during the supermoon total lunar eclipse day. The results show that the simulated salinity concentration fits adequately the observed data.

\section{Models performance verification}

The statistical indicators used for evaluating the performance of the numerical and analytical models are root mean squared error (RMSE); mean absolute error (ABSERR); the NashSutcliffe modeling efficiency index (EF); the goodness-offit $\left(R^{2}\right)$ and the $\%$ of deviation from observed streamflow (PBIAS). The statistical parameters were defined as follows (Moriasi et al., 2007; Stehr et al., 2008; Conversa et al., 2015):

$\mathrm{RMSE}=\sqrt{\left[\frac{\sum_{i=1}^{n}\left(O_{\text {meas }, i}-S_{\mathrm{perd}, i}\right)^{2}}{N}\right]}$,

$\operatorname{ABSERR}=\left[\frac{\sum_{i=1}^{n}\left(O_{\text {meas }, i}-S_{\text {perd }, i}\right)}{N}\right]$,

$\mathrm{EF}=1-\left[\frac{\sum_{i=1}^{n}\left(O_{\text {meas }, i}-S_{\text {perd }, i}\right)^{2}}{\sum_{i=1}^{n}\left(O_{\text {meas }, i}-\overline{O_{\text {meas }}}\right)^{2}}\right]$,

$$
\begin{aligned}
& R^{2}=\left[\frac{\sum_{i=1}^{n}\left(O_{\text {meas }, i}-\overline{O_{\text {meas }}}\right)\left(S_{\text {perd }, i}-\overline{S_{\text {perd }}}\right)}{\left(\sum_{i=1}^{n}\left(O_{\text {meas }, i}-\overline{O_{\text {meas }}}\right)^{2}\right)^{1 / 2}\left(\sum_{i=1}^{n}\left(S_{\text {perd }, i}-\overline{S_{\text {perd }}}\right)^{2}\right)^{1 / 2}}\right]^{2}, \\
& \text { PBIAS }=\left[\frac{\sum_{i=1}^{n}\left(O_{\text {meas }, i}-S_{\text {perd }, i}\right)}{\sum_{i=1}^{n}\left(O_{\text {meas }, i}\right)} 100\right],
\end{aligned}
$$

where $O_{\text {meas }, i}$ is the observed value and $S_{\text {perd }, i}$ the computed value of salinity or water level. $\bar{O}_{\text {meas }, i}$ is the mean observed salinity or water level data and $\overline{S_{\text {perd }}}$ is the mean computed salinity or water level.

The closer the values of RMSE and ABSERR to zero, and $R^{2}$ to unity, the better the model performance is evaluated (Abu El-Nasr et al., 2005). Percent bias (PBIAS) measures the average tendency, expressed as a percentage of the simulated data to be larger or smaller than their observed counterparts (Gupta et al., 1999). The optimal value of PBIAS is 0, with low-magnitude values indicating accurate model simulation (Moriasi et al., 2007). Positive values indicate model underestimation bias and negative values indicate model overestimation bias (Gupta et al., 1999). The EF (Nash and Sutcliffe, 1970) is a normalized statistic that determines the relative magnitude of the residual variance (noise) compared to the measured data variance (information). EF ranges between $-\infty$ and 1 ( 1 inclusive), with $\mathrm{EF}=1$; the closer the model EF efficiency is to 1 , the more accurate is the model. Values between 0 and 1 are generally viewed as acceptable levels of performance, whereas values $\leq 0$ indicate an unacceptable performance (Moriasi et al., 2007).

The indicators of the hydrodynamic-salinity intrusion model are summarized in Tables 6 and 7. In two models, the EF and $R^{2}$ coefficients are very near to unity. This result demonstrates the good performance of the analytical model. Also, this shows that the proposed coupled analytical model by Cai et al. (2016) is applicable and useful.

The statistical performances of the numerical model use water level for comparison. Values of statistical parameters indicated in Table 8 show good correlation model calculations and measurements during calibration and validation. 

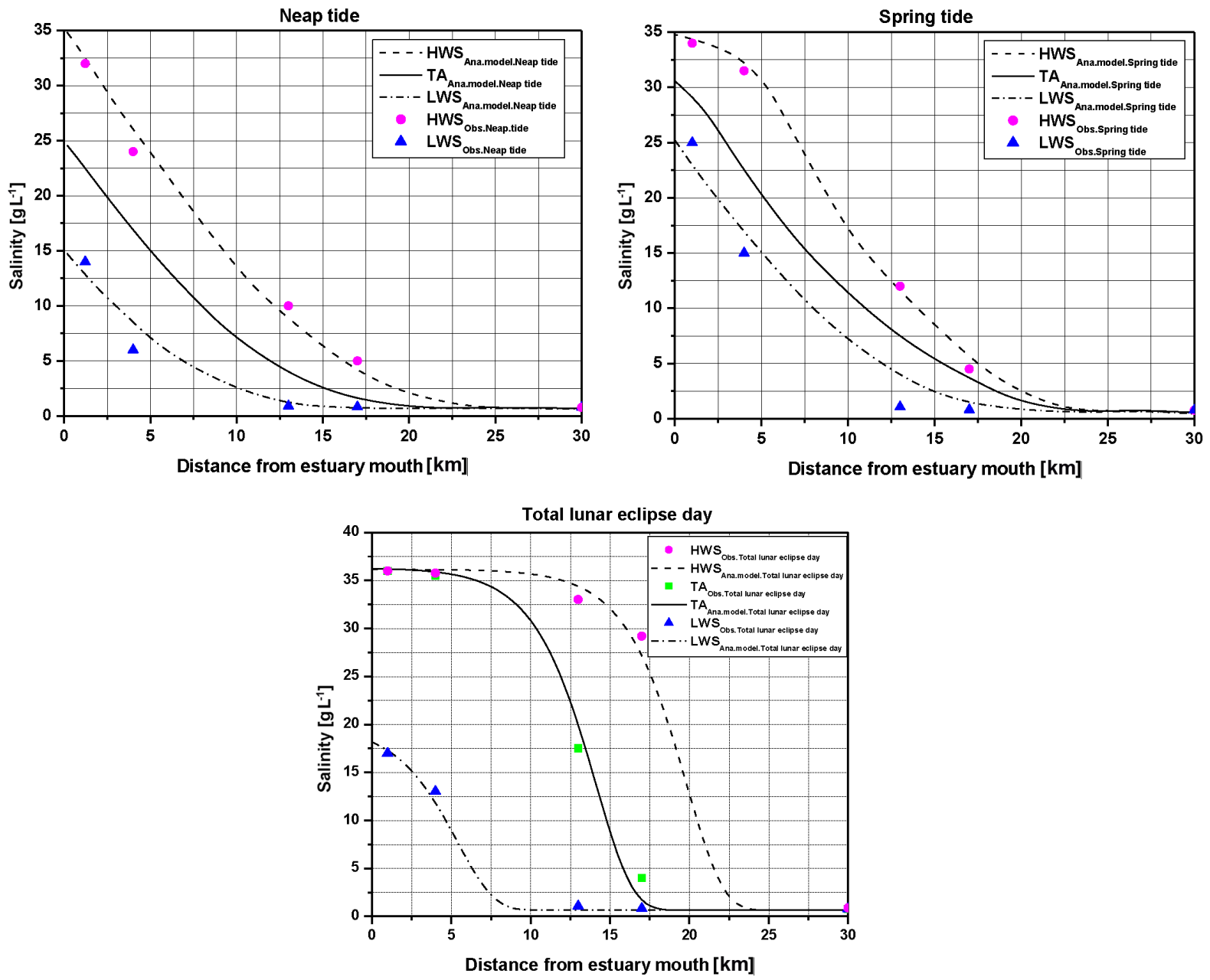

Figure 16. Salinity distributions in the Sebou estuary during spring tide, neap tide and supermoon total lunar eclipse day.

Table 8. Statistical indicators of Hydrodynamic model performance in calibration and validation.

\begin{tabular}{llllll}
\hline Statistical indicators of hydrodynamic model & RMSE [m] & ABSERR [m] & EF [-] & $R^{2}[-]$ & PBIAS [\%] \\
\hline Calibration (27.09.2015) & 0.34 & 0.21 & 0.94 & 0.93 & 0.94 \\
Validation (28.09.2015-29.09.2015) & 0.66 & 0.59 & 0.90 & 0.89 & 1.01 \\
\hline
\end{tabular}

These indicate that the model can estimate the water level at Kenitra fairly well.

The statistical indicators for the transport model are summarized in Table 9. The results show that the computed salinity concentration follows observed data, which suggest that the presented mass transport model is a reasonably efficient tool for predicting the impact of the supermoon total lunar eclipse on salt intrusion in alluvial estuaries.

\section{Supermoon total lunar eclipse impact}

The impact of the combination of a supermoon and a total lunar eclipse on river hydrodynamics is mainly caused by the moon being at its closest point to Earth, which gives extra gravitational pulling, and the alignment of Sun-EarthMoon. The maximum salinity at high water along the Sebou estuary has been described in Sect. 4. Supermoon and total lunar eclipse impact on the maximum salinity at different locations compared to the normal situation is given in Table 10 . The results clearly show that the astronomical event's impact on salinity intrusion is highly significant. The salinity increments in the four stations relative to the normal situation were $4.1 \mathrm{~g} \mathrm{~L}^{-1}(6.54 \%), 9.4 \mathrm{~g} \mathrm{~L}^{-1}(22.06 \%), 0.5 \mathrm{~g} \mathrm{~L}^{-1}$ $(26.32 \%)$ and $0.2 \mathrm{~g} \mathrm{~L}^{-1}(14.29 \%)$. This situation was unsuitable for drinking and agricultural proposes. 
Table 9. Statistical indicators of transport model performance in calibration.

\begin{tabular}{llllll}
\hline $\begin{array}{l}\text { Statistical indicators of transport } \\
\text { model in calibration }\end{array}$ & RMSE $\left[\mathrm{gL}^{-1}\right]$ & ABSERR $\left[\mathrm{gL}^{-1}\right]$ & EF [-] & $R^{2}[-]$ & PBIAS [\%] \\
\hline Oulad Berjel & 0.69 & 0.71 & 0.96 & 0.91 & 0.92 \\
Kenitra & 0.88 & 0.86 & 0.92 & 0.86 & 1.04 \\
Oulad Salma & 0.92 & 0.89 & 0.92 & 0.84 & 1.12 \\
\hline
\end{tabular}

Table 10. Comparisons salinity variation at HWS in different locations.

\begin{tabular}{lll}
\hline $\begin{array}{l}\text { Estuary } \\
\text { locations }\end{array}$ & $\begin{array}{l}\text { Normal situation } \\
\text { HWS salinity }\left(\mathrm{g} \mathrm{L}^{-1}\right)\end{array}$ & $\begin{array}{l}\text { supermoon eclipse } \\
\text { HWS salinity }\left(\mathrm{g} \mathrm{L}^{-1}\right)\end{array}$ \\
\hline Oulad Berjel & 28.5 & 32.6 \\
Kenitra & 16.6 & 26.0 \\
Oulad Salma & 00.7 & 01.2 \\
M'Rabeh & 00.6 & 00.8 \\
\hline
\end{tabular}

Furthermore, Fig. 16 shows the profiles of salinity during supermoon total lunar eclipse compared with springneap tides. It appears that the salt intrusion curve computed in the neap-spring tides are recession type, while it becomes a dome-type shape at eclipse day. According to Nguyen et al. (2012), this is subjected to changes in the degree of convergence of the cross-sectional profile, and the effect of the mixing due to freshwater discharge (i.e. that increasing the tidal amplitude at the mouth tends to produce shorter convergence lengths of the cross-sectional area and width). The convergence or divergence of the channel can dramatically change the shape of the salt intrusion curve (Gay and O'Donnell, 2007; Cai et al., 2015). In addition, Savenije (2005) shows that the recession-type curve occurs in narrow estuaries having a near-prismatic shape, high river discharge and dome-type shape, which occurs in strong funnel-shaped estuaries (with a short convergence length) (see Appendix A). At eclipse day, when the channel converges strongly, the mixed water retains relatively higher salinity from the estuary mouth. However, salinity profiles under all spring-neap tides show a gradual decrease from the mouth to the upstream reach.

Additionally, it can be shown that the part of the Sebou estuary that is affected by the supermoon total lunar eclipse is from 20 to $25 \mathrm{~km}$ upstream of the river mouth. A water level rise as showed above during this exceptional event moves the excessive salinity $\left(25 \mathrm{~g} \mathrm{~L}^{-1}\right)$ until $20 \mathrm{~km}$ upstream. Moreover, water level rise causes large augmentation of salinity in the mesohaline zone of the Sebou estuary. Also, if we considerer Kenitra location, an increase of water level for $0.8 \mathrm{~m}$ causes an increase of $9.4 \mathrm{~g} \mathrm{~L}^{-1}$ in salinity witch correspond to a salinity augmentation of $11.75 \mathrm{~g} \mathrm{~L}^{-1}$ per meter of increased water level. At the Oulad Salma drinking water station salinity increased to a value of $1.2 \mathrm{~g} \mathrm{~L}^{-1}$ that exceeds the limit value of $0.5 \mathrm{gL}^{-1}$ recommended by the World Health Organization (WHO) for drinking water.

Computations using hybrid (hydrodynamic) and salt intrusion models during the supermoon total lunar eclipse required the recalculation of the geometric parameters of the estuary, i.e., cross-sectional area $A_{0}$, convergence length $a$ and the optimization of the dispersion coefficient $D$. Geometry is one of the most important parameters in the hydrodynamic and salt intrusion models. It affects the character of the salinity distribution and appears prominently in the shape of salt intrusion curves during extreme events. Computed results reveal that variations in the sensitivity of these parameters are likely to depend on changes in geometric characteristics.

\section{Conclusions}

The purpose of this paper was to study the impact of the supermoon total lunar eclipse of 28 September 2015 on salt intrusion in Sebou river estuary. It is, to our knowledge, the first time that this infrequent phenomenon has been studied in terms of its influence on water quality. Field measurements showed a change of the salinity profiles form along the estuary axis and a notable water level rise, compared with normal situations studied in our earlier works. In addition, results show that the average salt content increased in the reach between 0 and $25 \mathrm{~km}$, as a result of water volume rise at the mouth. A hybrid model proposed by Cai et al. (2014) coupled to an analytical salt intrusion model in alluvial estuaries (Savenije, 2005) and a numerical model (HEC-RAS) have been applied in the Sebou river estuary. Calculations during the supermoon total lunar eclipse using the coupled hybridsalt intrusion model required the recalculation of the geometric parameters of the estuary, i.e., cross-sectional area $A_{0}$ and convergence length $a$. A good fit was obtained between computed and observed salinity during this extreme event. These models reproduce very well the salinity rise. Statistical indicators show that these models fit adequately salinity observations in the Sebou estuary.

A comparison between the two applied models is not the objective of this study since each one can be applied for specific management purposes. The analytical models are helpful for situations where a quick longitudinal salinity profile is needed. Furthermore, the numerical 1-D model is powerful where a temporal salinity variation is carried out in a spe- 
cific location, but it needs more data and time for its implementation. Hence, these tools can be very helpful for water managers and engineering to make preliminary estimates on the salt intrusion along the estuary axis even during extreme events. These extreme events can concern similar the supermoon total lunar eclipse, see level rise due to climate change, a sea tsunami.

Finally, the impact of extreme events on the water quality of Sebou estuary should be considered by managers. Rapid interventions, based on the predictions of our mathematical models can thus be taken. These interventions may involve the pumping station closure for example.

\section{Nomenclature and abbreviations list}

a Convergence length of cross-sectional area [m]

A Tidally averaged cross-sectional area [m]

$A_{0} \quad$ Tidally averaged cross-sectional area at the estuary mouth [m]

$b \quad$ Convergence length of width [m]

$B \quad$ Estuary width [m]

$B_{1} \quad$ Width at inflection point [m]

$B_{f} \quad$ Stream width [m]

$C_{z} \quad$ Coefficient of Chezy $\left[\mathrm{m}^{0.5} \mathrm{~s}^{-1}\right]$

$d \quad$ Convergence length of depth [m]

$D \quad$ Longitudinal dispersion $\left[\mathrm{m}^{2} \mathrm{~s}^{-1}\right]$

$D_{0} \quad$ Longitudinal dispersion at estuary mouth $\left[\mathrm{m}^{2} \mathrm{~s}^{-1}\right]$

$D_{1} \quad$ Longitudinal dispersion at inflection point $\left[\mathrm{m}^{2} \mathrm{~s}^{-1}\right]$

$D_{\text {up }} \quad$ Longitudinal dispersion at upstream $\left[\mathrm{m}^{2} \mathrm{~s}^{-1}\right]$

$E$ Tidal excursion [m]

$E_{0}$ Tidal excursion starting from the estuary mouth [m]

$E_{1} \quad$ Tidal excursion starting from the inflection point $[\mathrm{m}]$

$f \quad$ Darcy-Weisbach friction factor [-]

$F \quad$ Froude number [-]

$F_{\mathrm{D}} \quad$ Densimetric Froude number [-]

$g \quad$ Acceleration due to gravity $\left[\mathrm{m} \mathrm{s}^{2}\right]$

$h \quad$ Averaged estuary depth [m]

$h_{0} \quad$ Estuary depth at the mouth [m]

$H \quad$ Tidal range [m]

$H_{0} \quad$ Tidal range at estuary mouth [m]

$H_{1} \quad$ Tidal range at inflection point [m]

$H \quad$ Tidal range $[\mathrm{m}]$

$K_{S} \quad$ Manning-Strickler friction factor $\left[\mathrm{m}^{1 / 3} \mathrm{~s}^{-1}\right]$

$K \quad$ Van der Burgh's coefficient [-]

$m \quad$ Number of observations [-]

$N \quad$ Canter-Cremers' estuary number [-]

$N_{\mathrm{R}} \quad$ Estuarine Richardson number [-]

$Q \quad$ Freshwater discharge $\left[\mathrm{m}^{3} \mathrm{~s}^{-1}\right]$
$Q_{\text {up }} \quad$ Freshwater discharge at upstream $\left[\mathrm{m}^{3} \mathrm{~s}^{-1}\right]$

$R \quad$ Hydraulic radius [m]

$r_{\mathrm{s}} \quad$ Storage width ratio [-]

$S \quad$ Steady-state salinity $\left[\mathrm{g} \mathrm{L}^{-1}\right]$

$S_{0} \quad$ Steady-state salinity at the estuary mouth $\left[\mathrm{g} \mathrm{L}^{-1}\right.$ ]

$S^{*} \quad$ Steady-state salinity [-]

C Salinity concentration $\left[\mathrm{g} \mathrm{L}^{-1}\right]$

$C_{n+1} \quad$ Concentration of a constituent at present time step $\left[\mathrm{g} \mathrm{m}^{-3}\right.$ ]

$C_{\text {up }}^{*} \quad$ QUICKEST concentration of a constituent at upstream $\left[\mathrm{g} \mathrm{m}^{-3}\right]$

$C_{n} \quad$ Concentration of a constituent at previous time step $\left[\mathrm{g} \mathrm{m}^{-3}\right]$

$T \quad$ Tidal period [s]

$t \quad$ Time [s]

$u_{0} \quad$ Velocity of the freshwater discharge at estuary mouth $\left[\mathrm{m} \mathrm{s}^{-1}\right]$

$v \quad$ Tidal velocity amplitude $\left[\mathrm{m} \mathrm{s}^{-1}\right]$

$v_{0} \quad$ Tidal velocity amplitude at estuary mouth $\left[\mathrm{m} \mathrm{s}^{-1}\right.$ ]

$v_{1} \quad$ Tidal velocity amplitude at inflection point $\left[\mathrm{m} \mathrm{s}^{-1}\right]$

$V_{n+1} \quad$ Volume of the water quality cell at present time step $\left[\mathrm{m}^{3}\right]$

$V_{n} \quad$ Volume of the water quality cell at previous time step $\left[\mathrm{m}^{3}\right]$

$L \quad$ Salt intrusion length [m]

$L^{*} \quad$ Salt intrusion length [-]

$x \quad$ Distance from the estuary mouth $[\mathrm{m}]$

$x^{*} \quad$ Distance from the estuary mouth [-]

$x_{1} \quad$ First inflection point [m]

$\eta \quad$ Tidal amplitude $[\mathrm{m}]$

$c_{0} \quad$ Classical wave celerity $\left[\mathrm{m} \mathrm{s}^{-1}\right]$

$\beta_{0} \quad$ Bottom slope [-]

$q_{l} \quad$ Lateral inflow per unit length $\left[\mathrm{m}^{2} \mathrm{~s}^{-1}\right]$

$\sigma_{s} \quad$ Variance of the measured salinity $\left[\mathrm{m}^{2} \mathrm{~s}^{-1}\right]$

$\chi \quad$ Friction number [-]

$\omega \quad$ Tidal frequency $\left[\mathrm{s}^{-1}\right]$

$\rho \quad$ Fluid density $\left[\mathrm{kg} \mathrm{m}^{-3}\right]$

$\Delta \rho \quad$ Density difference over the intrusion length $\left[\mathrm{kg} \mathrm{m}^{-3}\right]$

$\delta \quad$ Damping number [-]

$\varepsilon \quad$ Phase lag between HW and HWS (or LW and LWS) [-]

$\zeta \quad$ Tidal amplitude to depth ratio [-]

$\gamma \quad$ Estuary shape number [-]

$\varphi_{Z} \quad$ Phase of water level [-]

$\varphi_{U} \quad$ Phase of velocity [-]

$\lambda \quad$ Celerity number [-]

$\mu \quad$ Velocity number $[-]$ 


\section{Abbreviations list}

$\begin{array}{ll}\text { LWS } & \text { low water slack } \\ \text { HWS } & \text { high water slack } \\ \text { LW } & \text { low water } \\ \text { HW } & \text { high water } \\ \text { TA } & \text { tidal average } \\ \text { RMSE } & \text { root mean squared error } \\ \text { ABSERR } & \text { mean absolute error } \\ \text { EF } & \text { Nash-Sutcliffe index } \\ R^{2} & \text { goodness-of-fit } \\ \text { PBIAS } & \text { \% of deviation from } \\ & \text { observed streamflow }\end{array}$

\section{Data availability}

The data used in the study (analytical and numerical models) were provided by local water authorities (i.e. ANP, National Agency of Ports and Water Services of Kenitra town) in a row format (AutoCAD files). On the other hand, some topographic and satellite maps were exploited. 


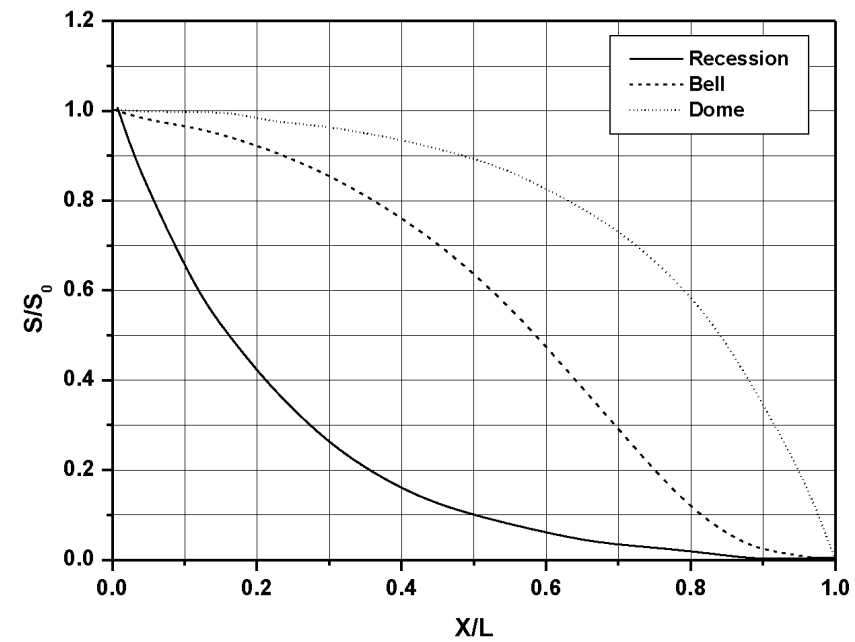

Figure A1. Three types of salt intrusion curves, in which $L$ is the salt intrusion length, $x$ is the distance from the mouth, $S$ is the salinity at the mouth and $S_{0}$ is the salinity corresponding with the distance.

\section{Appendix A: Types of salt intrusion and shape of salt intrusion curves}

Salinity distribution is a veritable fingerprint of each estuary and in direct relation to both its geometric form and hydrology. For partially mixed and well-mixed estuaries, a number of designations are used to classify salinity profiles into three types depending on their shape. The following types are distinguished (Savenije, 2005, 2012) (see Fig. A1):

- Recession shape, which occurs in narrow estuaries with a near-prismatic shape and a high river discharge (Savenije, 2005, 2012).

- Bell shape, which occurs in estuaries that have a trumpet shape, i.e. a long convergence length in the upstream part, but a short convergence length near the mouth (Savenije, 2005, 2012).

- Dome shape, which occurs in strong funnel-shaped estuaries (with a short convergence length) (Savenije, 2005, 2012).

\section{Appendix B: Empirical models (Savenije, 2003a)}

Rigter (1973):

$L^{\mathrm{LWS}}=1.5 \pi \frac{h_{0}}{f}\left(F_{D}^{-1} N^{-1}-1.7\right)=4.7 \pi \frac{h_{0}}{f} F_{D}^{-1.0} N^{-1}$.

Fischer (1974):

$L^{\mathrm{LWS}}=17.7 \frac{h_{0}}{f^{0.625}} F_{D}^{-0.75} N^{-0.25}$.

Van der Burgh (1972):

$L^{T A}=-26 \frac{h_{0}}{K} \frac{\sqrt{g h_{0}}}{v_{0}} \frac{v_{0}}{u_{0}} N^{0.5}=26 . \pi \frac{h_{0}}{K} F^{-1.0} N^{-0.5}$.

Van Os and Abraham (1990):

$L^{\mathrm{LWS}}=4.4 \frac{h_{0}}{f} F_{D}^{-1} N^{-1}$,

where $h_{0}$ is the tidal average depth, $v_{0}$ is the maximum tidal velocity, $u_{0}$ is the velocity of fresh water, $N$ is the CanterCremers' estuary number, $K$ is the Van der Burgh's coefficient, $f$ is the Darcy-Weisbach's coefficient, $F$ is the Froude number and $F_{\mathrm{D}}$ is the densimetric Froude number. 
Acknowledgements. The authors would like to express their gratitude to O. Khabali, H. Qanza, M. Hachimi, O. El Mountassir and I. Baimik for the efforts in the field measurements during the supermoon total lunar eclipse day. The authors would also like to acknowledge the technicians at the water services of Kenitra, and the engineers of the National Agency of Ports for their availability and collaboration.

Edited by: A. Ghadouani

Reviewed by: two anonymous referees

\section{References}

Aertsl, J. C. J. H., Hassan, A., Savenije, H. H. G., and Khan, M.: Using GIS tools and rapid assessment techniques for determining salt intrusion: stream a river basin management instrument, Phys. Chem. Earth, 25, 265-273, 2000.

An, Q., Wu, Y., Taylor, S., and Zhao, B.: Influence of the Three Gorges Project on saltwater intrusion in the Yangtze River Estuary, Environ. Geol., 56, 1679-1686, 2009.

Billah, M., Rahman, M. M., Paul, S., Hasan, M. A., and Islam, A. K. M. S. L.: Impact of climate change on river flows in the southwest region of Bangladesh, Proceedings of the 5th International Conference on Water and Flood Management (ICWFM 2015), 6-8 March, 2015, IWFM, BUET, Dhaka, Bangladesh, Vol. 1, 581$590,2015$.

Brockway, R., Bowers, D., Hoguane, A., Dove, V., and Vassele, V.: A note on salt intrusion in funnel-shaped estuaries: Application to the Incomati estuary, Mozambique, Estuar. Coast. Shelf S., 66, $1-5,2006$

Brunner, G. W.: HEC-RAS River Analysis System Hydraulic Reference Manual (version 4.1), US Army Corp of Engineers, Hydrologie Engineering Center (HEC), Davis California, USA, 2010.

Cai, H., Savenije, H. H. G., and Tofflon, M.: A new analytical framework for assessing the effect of sea-level rise and dredging on tidal damping in estuaries, J. Geophys. Res.-Ocean., 117, C09023, doi:10.1029/2012JC008000, 2012a.

Cai, H., Savenije, H. H. G., Yang, Q., Ou, S., and Lei, Y.: Influence of river discharge and dredging on tidal wave propagation; Modaomen estuary case, J. Hydraul. Eng., 138, 885-896, doi:10.1061/(ASCE)HY.1943-7900.0000594, 2012b.

Cai, H., Savenije, H. H. G., and Toffolon, M.: A hybrid analytical model for assessing the effect of river discharge on tidal damping, applied to the modaomen estuary, Coast. Dynam., http://www.coastaldynamics2013.fr/pdf_ files/024_Cai_Huayang.pdf (last access: 11 March 2016), 2013.

Cai, H., Savenije, H. H. G., and Jiang, C.: Analytical approach for predicting fresh water discharge in an estuary based on tidal water level observations, Hydrol. Earth Syst. Sci., 18, 4153-4168, doi:10.5194/hess-18-4153-2014, 2014a.

Cai, H., Savenije, H. H. G., and Toffolon, M.: Linking the river to the estuary: influence of river discharge on tidal damping, Hydrol. Earth Syst. Sci., 18, 287-304, doi:10.5194/hess-18-2872014, 2014b.

Cai, H., Savenije, H. H. G., and Gisen, J. I. A.: A coupled analytical model for salt intrusion and tides in convergent estuaries, Hydrol. Sci. J., Hydrological Sciences Journal, 61, 402-419, 2016.
Cai, H., Savenije, H. H., Zuo, S., Jiang, C., and Chua, V. P.: A predictive model for salt intrusion in estuaries applied to the Yangtze estuary, J. Hydrol., 529, 1336-1349, 2015 b.

Chow, V. T.: Open-channel Hydraulics, McGraw-Hill International Editions, McGraw-Hill Book Co., New York, 680 pp., 1959.

Combe, M.: Study of tidal cycle in the Sebou estuary during low water, 108 pp., Rapport inédit, Rabat, MTPC/DH DRE, 1966.

Combe, M.: Hydrogeological maps of the Plain Gharb 1/100 000, Notes and Memoirs of the Geological Service of Morocco, 221 bis, Rabat, Morocco, 1969.

Conversa, G., Bonasia, A., Di Gioia, F., and Elia, A.: A decision support system $(\mathrm{GesCoN})$ for managing fertigation in vegetable crops. Part II-model calibration and validation under different environmental growing conditions on field grown tomato, Frontiers in plant science, Vol. 6, 2015.

Cowan, W. L.: Estimating hydraulic roughness coefficients, Agr. Eng., 37, 473-475, 1956.

Dronkers, J. J.: Tidal computations in River and Coastal Waters, Elsevier, 518 pp., New York, Interscience Publishers, 1964.

Espenak, F.: Lunar Eclipses, http://eclipse.gsfc.nasa.gov/LEdecade/ LEdecade1991.html (last access: 2 March 2016), 1991-2000.

Elias, E. P., Gelfenbaum, G., and Van der Westhuysen, A. J.: Validation of a coupled wave-flow model in a high-energy setting: The mouth of the Columbia River, J. Geophys. Res.-Ocean., 117, doi:10.1029/2012JC008105, 2012.

El-Nasr, A. A., Arnold, J. G., Feyen, J., and Berlamont, J.: Modelling the hydrology of a catchment using a distributed and a semi-distributed model, Hydrol. Process., 19, 573-587, 2005.

Fischer, H. B.: Discussion of Minimum length of salt intrusion in estuaries, edited by: Rigter, B. P., J. Hydraul. Div., 99, 14751496, 1974.

Fischer, H. B., List, E. J., Koh, R. C. Y., Imberger, J., and Brooks, N. H.: Mixing in Inland and Coastal Waters, Academic Press, New York, 483 pp., 1979.

Friedrichs, C. T. and Aubrey, D. G.: Tidal propagation in strongly convergent channels, J. Geophys. Res. Oceans, 99, 3321-3336, 1994.

Gay, P. and O'Donnell, J.: Comparison of the salinity structure of the Chesapeake Bay, the Delaware Bay and Long Island Sound using a linearly tapered advection-dispersion model, Estuar. Coast., 32, 68-87, doi:10.1007/s12237-008-9101-4 2009.

Gay, P. S. and O'Donnell, J.: A simple advection-dispersion model for the salt distribution in linearly tapered estuaries, J. Geophys. Res., 112, C070201, doi:10.1029/2006JC003840, 2007.

Gisen, J. I. A., Savenije, H. H. G., Nijzink, R. C., and Wahab, A. K. Abd.: Testing a 1-D analytical salt intrusion model and its predictive equations in Malaysian estuaries, Hydrol. Sci. J., 60, 156-172, 2015a.

Gisen, J. I. A., Savenije, H. H. G., and Nijzink, R. C.: Revised predictive equations for salt intrusion modelling in estuaries, Hydrol. Earth Syst. Sci., 19, 2791-2803, doi:10.5194/hess-19-27912015, 2015b

Godin, G.: Modification of river tides by the discharge, J. Waterw. Port. C-ASCE, 111, 257-274, 1985.

Godin, G.: The propagation of tides up rivers with special considerations on the upper saint lawrence river, Estuar. Coast., 48, 307324, 1999. 
Gupta, H. V., Sorooshian, S., and Yapo, P. O.: Status of automatic calibration for hydrologic models: comparison with multilevel expert calibration, J. Hydrol. Eng., 4, 135-143, 1999.

Haddout, S., Maslouhi, A., and Igouzal, M.: Mathematical modeling of the flow regime in the Sebou river estuary (Morocco), National Water Information System Congress, NWIS 2014, 2-4 December, Rabat, 2014.

Haddout, S., Maslouhi, A., and Igouzal, M.: Predicting of salt water intrusion in the Sebou river estuary (Morocco), J. Appl. Water Eng. Res., 1-11, doi:10.1080/23249676.2015.1124029, 2015.

Haddout, S., Maslouhi, A., Magrane, B., and Igouzal, M.: Study of salinity variation in the Sebou River Estuary (Morocco), Desalination and Water Treatment, 57, 17075-17086, 2016.

Horrevoets, A. C., Savenije, H. H. G., Schuurman, J. N., and Graas, S.: The influence of river discharge on tidal damping in alluvial estuaries, J. Hydrol., 294, 213-228, 2004.

Hughes, S. W., Hosokawa, K., Carroll, J., Sawell, D., and Wilson, C.: In the red shadow of the Earth, Phys. Educ., 50, p. 741, 2015.

Igouzal, M. and Maslouhi, A.: Elaboration of management tool of a reservoir dam on the Sebou river (Morocco) using an implicit hydraulic model, J Hydraul. Res., 43, 125-130, 2005.

Igouzal, M., Mouchel, J. M., Tamoh, K., and Maslouhi, A.: Modelling the hydraulic regime and the water quality of Sebou River (Morocco): first results, IAHS Publ., 299, p. 75, 2005.

Ippen, A. T.: Tidal dynamics in estuaries, part I: Estuaries of rectangular section, in Estuary and Coastline Hydrodynamics, edited by: Ippen, A. T., McGraw-Hill, New York, 493-521, 1966.

Jay, D. A.: Green law revisited-tidal long-wave propagation in channels with strong topography, J. Geophys. Res., 96, 20585-20598, 1991.

Jay, D. A., Leffler, K., and Degens, S.: Long-term evolution of columbia river tides, J. Waterw. Port C-ASCE, 137, 182-191, 2011.

Jeong, S., Yeon, K., Hur, Y., and Oh, K.: Salinity intrusion characteristics analysis using EFDC model in the downstream of Geum River, J. Environ. Sci., 22, 934-939, 2010.

Kärnä, T., Baptista, A. M., Lopez, J. E., Turner, P. J., McNeil, C., and Sanford, T. B.: Numerical modeling of circulation in highenergy estuaries: A Columbia River estuary benchmar, Ocean Model., 88, 54-71, 2015.

Kuijper, K. and Van Rijn, L. C.: Analytical and numerical analysis of tides and salinities in estuaries; part II: salinity distributions in prismatic and convergent tidal channels, Ocean Dynam., 61, 1743-1765, 2011.

Kukulka, T. and Jay, D. A.: Impacts of columbia river discharge on salmonid habitat: 1. A nonstationary fluvial tide model, J. Geophys. Res.-Ocean., 108, 3293, doi:10.1029/2002JC001382, 2003.

Lanzoni, S. and Seminara, G.: On tide propagation in convergent estuaries, J. Geophys. Res.-Ocean., 103, 30793-30812, 1998.

Lewis, R. E. and Uncles, R. J.: Factors affecting longitudinal dispersion in estuaries of different scale, Ocean Dynam., 53, 197-207, doi:10.1007/s10236-003-0030-2, 2003.

Li, J., Li, D., and Wang, X.: Three-dimensional unstructured-mesh eutrophication model and its application to the Xiangxi River, China, J. Environ. Sci., 24, 1569-1578, 2012.

Leblond, P. H.: Tidal propagation in shallow rivers, J. Geophys. Res.-Ocean., 83, 4717-4721, 1978.
Mai, B. X., Fu, J. M., Sheng, G. Y., Kang, Y. H., Lin, Z., Zhang, G., and Zeng, E. Y.: Chlorinated and polycyclic aromatic hydrocarbons in riverine and estuarine sediments from Pearl River Delta, China, Environ. Poll., 117, 457-474, 2002.

Marquardt, D. W.: An algorithm for least-squares estimation of nonlinear parameters, J. Soc. Indust. Appl. Math., 11, 431-441, 1963.

Moriasi, D. N., Arnold, J. G., Van Liew, M. W., Bingner, R. L., Harmel, R. D., and Veith, T. L.: Model evaluation guidelines for systematic quantification of accuracy in watershed simulations, Trans. Asabe, 50, 885-900, 2007.

NASA (National Aeronautics and Space Administration): http:// www.nasa.gov/ (last access: 18 August 2016), 2015.

Nash, J. E. and Sutcliffe, J. V.: River flow forecasting through conceptual models part I-A discussion of principles, J. Hydrol., 10, 282-290, doi:10.1016/0022-1694(70)90255-6, 1970.

Nguyen, A. D.: Salt Intrusion, Tides and Mixing in Multi-Channel Estuaries: PhD: UNESCO-IHE Institute, Delft, CRC Press, 176 pp., 2008.

Nguyen, A. D. and Savenije, H. H.: Salt intrusion in multi-channel estuaries: a case study in the Mekong Delta, Vietnam, Hydrol. Earth Syst. Sci., 10, 743-754, doi:10.5194/hess-10-743-2006, 2006.

Nguyen, A. D., Savenije, H. H., Pham, D. N., and Tang, D. T.: Using salt intrusion measurements to determine the freshwater discharge distribution over the branches of a multi-channel estuary: The Mekong Delta case, Estuar. Coast. Shelf S., 77, 433-445, 2008.

Nguyen, D. H., Umeyama, M., and Shintani, T.: Importance of geometric characteristics for salinity distribution in convergent estuaries, J. Hydrol., 448, 1-13, 2012.

NOC (National Oceanography Centre): http://noc.ac.uk/ (last access: 18 August 2016), 2015.

Nylén, L. and Ramel, E.: The effects of inlet sedimentation on water exchange in Maha Oya Estuary, Sri Lanka, 130 pp., 2012.

Prandle, D.: Salinity intrusion in estuaries, J. Phys. Oceanogr., 11, 1311-1324, 1981.

Prandle, D. and Rahman, M.: Tidal response in estuaries, J. Phys. Oceanogr., 10, 1552-1573, 1980.

Rigter, B. P.: Minimum length of salt intrusion in estuaries, J. Hydr. Eng. Div.-ASCE, 99, 1475-1496, 1973.

Savenije, H. H. G.: A one-dimensional model for salinity intrusion in alluvial estuaries, J. Hydrol., 85, 87-109, 1986.

Savenije, H. H. G.: Salt intrusion model for high-water slack, lowwater slack, and mean tide on spread sheet, J. Hydrol., 107, 9-18, 1989.

Savenije, H. H. G.: Predictive model for salt intrusion in estuaries, J. Hydrol., 148, 203-218, 1993 a.

Savenije, H. H. G.: Determination of estuary parameters on basis of Lagrangian analysis, J. Hydraul. Eng.-ASCE, 119, 628-642, $1993 b$.

Savenije, H. H. G.: Analytical expression for tidal damping in alluvial estuaries, J. Hydraul. Eng.-ASCE, 124, 615-618, 1998.

Savenije, H. H. G.: Salinity and tides in alluvial estuaries, Amsterdam, Elsevier, 197 pp., 2005.

Savenije, H. H. G.: Comment on "A note on salt intrusion in funnelshaped estuaries: Application to the Incomati estuary, Mozambique" by Brockway et al. (2006), Estuar. Coast. Shelf S., 68, 703-706, 2006. 
Savenije, H. H. G., Toffolon, M., Haas, J., and Veling, E. J. M.: Analytical description of tidal dynamics in convergent estuaries, J. Geophys. Res.-Ocean., 113, C10025, doi:10.1029/2007JC004408, 2008.

Savenije, H. H. G.: Salinity and Tides in Alluvial Estuaries, second ed., available at: www.salinityandtides.com (last access: 8 October 2015). 2012.

Savenije, H. H. G.: Prediction in ungauged estuaries: An integrated theory, Water Resour. Res., 51, 2464-2476, 2015.

Shaha, D. C. and Cho, Y.-K.: Determination of spatially varying Van der Burgh's coefficient from estuarine parameter to describe salt transport in an estuary, Hydrol. Earth Syst. Sci., 15, 1369-1377, doi:10.5194/hess-15-1369-2011, 2011.

Stehr, A., Debels, P., Romero, F., and Alcayaga, H.: Hydrological modelling with SWAT under conditions of limited data availability: evaluation of results from a Chilean case study, Hydrol. Sci. J., 53, 588-601, 2008.

Stronach, J. A. and Murty, T. S.: Nonlinear river-tidal interactions in the Fraser River, Canada, Mar. Geod., 13, 313-339, 1989.

Toffolon, M. and Savenije, H. H. G.: Revisiting linearized onedimensional tidal propagation, J. Geophys. Res.-Ocean., 116, C07007, doi:10.1029/2010JC006616, 2011.

Toffolon, M., Vignoli, G., and Tubino, M.: Relevant parameters and finite amplitude effects in estuarine hydrodynamics, J. Geophys. Res.-Ocean., 111, C10014, doi:10.1029/2005JC003104, 2006.

Van der Burgh, P.: Ontwikkeling van een methode voor het voorspellen van zoutverdelingen in estuaria, kanalen en zeeen, Rijkwaterstaat, Rapport, 10-72, 1972.
Van Os, A. G. and Abraham, G.: Density currents and salt intrusion, Lecture Note for Hydraulic Engineering Course at IHE-Delft, Delft Hydraulics, Delft, the Netherlands, 1990.

$\mathrm{Wu}, \mathrm{H}$. and Zhu, J.: Advection scheme with 3rd high-order spatial interpolation at the middle temporal level and its application to saltwater intrusion in the Changjiang Estuary, Ocean Model., 33, 33-51, 2010.

Xu, Y., Zhang, W., Chen, X., Zheng, J., Chen, X., and Wu, H.: Comparison of Analytical Solutions for Salt Intrusion Applied to the Modaomen Estuary, J. Coast. Res., 31, 735-741, 2015.

Xue, P., Chen, C., Ding, P., Beardsley, R. C., Lin, H., Ge, J., and Kong, Y.: Saltwater intrusion into the Changjiang River: A model-guided mechanism study, J. Geophys. Res.-Ocean., 114, doi:10.1029/2008JC004831, 2009.

Zhao, L., Zhang, X., Liu, Y., He, B., Zhu, X., Zou, R., and Zhu, Y.: Three-dimensional hydrodynamic and water quality model for TMDL development of Lake Fuxian, China, J. Environ. Sci., 24, 1355-1363, 2012.

Zhang, E. F., Savenije, H. H. G., Chen, S. L., and Mao, X. H.: An analytical solution for tidal propagation in the Yangtze Estuary, China, Hydrol. Earth Syst. Sci., 16, 3327-3339, doi:10.5194/hess-16-3327-2012, 2012. 